\title{
The genus Syzygium (Myrtaceae) in Vanuatu
}

\author{
S.H. Tuiwawa ${ }^{1,2,4}$, L.A. Craven ${ }^{1}$, C. Sam ${ }^{3}$, M.D. Crisp ${ }^{2}$
}

Key words

biogeography

ecology

Myrtaceae

systematics

Syzygium

taxonomy

Vanuatu

\begin{abstract}
Twenty species of Syzygium occur in Vanuatu of which eighteen are indigenous (six being endemic and one being an ancient introduction) and two are recently introduced. Three species are newly described: $S$. chanelii, S. flabellum and S. vanuatuense. The Syzygium flora of Vanuatu has strong links at species level to that of the Solomon Islands and Fiji, less strong links to elsewhere in the southwest Pacific and apparently no links to New Caledonia. Descriptions are provided for each species occurring in Vanuatu and identification keys are provided for flowering and vegetative material.
\end{abstract}

Published on 23 August 2013

\section{INTRODUCTION}

With c. 1200 species, Syzygium is the largest genus in Myrtaceae. It has a subtropical to tropical distribution, from Africa extending east to the Hawaiian Islands and from India and China southwards to southern Australia and New Zealand. The centres of diversity are the southern Asian, Southeast Asian, Malesian, Australian and New Caledonian regions, with decreasing species richness elsewhere (Craven 2001, Parnell et al. 2006).

A monograph of the woody flora of Vanuatu is yet to be published and there is little published information available on this component of its flora. Some species are recorded in Guillaumin's (1931) enumeration and Wheatley's (1992) guide; neither of which are adequate as a flora per se of Vanuatu. In view of there being an account of Syzygium available for Fiji (Smith 1985; in which Cleistocalyx and Piliocalyx were treated as genera distinct from Syzygium) and New Caledonia (Dawson 1999; this did not include Piliocalyx of which c. 20 species occur in New Caledonia), and current work in progress by the second author on Syzygium in the Solomon Islands, a study of the genus in Vanuatu was considered warranted. Not only would this fill a gap in knowledge of Syzygium in the southwestern Pacific but, as the Vanuatu archipelago occupies a central position with respect to the Solomon Islands, Fiji and New Caledonia, such a study might therefore be of interest biogeographically. Vanuatu is an archipelago of more than 80 islands spread across c. $830 \mathrm{~km}$ between c. $13^{\circ} \mathrm{S}$ and $21^{\circ} \mathrm{S}$ latitude and its major islands are shown in Map 1. Its climate is tropical with two seasons, the trade wind season occurring between May and October, and the hurricane season between November and April. The average yearly rainfall ranges from $4000 \mathrm{~mm}$ in the northern Banks and Torres Islands to $2200 \mathrm{~mm}$ in the southern islands. The average annual temperature ranges from $26.1^{\circ} \mathrm{C}$ in the northern islands to $24.6{ }^{\circ} \mathrm{C}$ in the central and to $23.5^{\circ} \mathrm{C}$ in the southertn islands (Giovanelli 1966).

\footnotetext{
1 Australian National Herbarium, CSIRO Plant Industry, GPO Box 1600, Canberra, ACT 2601, Australia;

corresponding author e-mail: senilolia.heilala@yahoo.com.

2 Research School of Biology, The Australian National University, Canberra, ACT 0200, Australia.

${ }^{3}$ Forestry Department, Port Vila, Efate, Vanuatu.

${ }^{4}$ Present address: Institute of Applied Science, The University of the South Pacific, Suva, Fiji Islands.
}

Based on the classification of Syzygium by Craven \& Biffin (2010), nineteen of the Vanuatuan species of Syzygium belong in subg. Syzygium and the remaining species, S. chanelii, belongs in sect. Piliocalyx. Indigenous species in common between Vanuatu, the Solomon Islands and New Guinea may be indicative of a west to east route of dispersal, however, the possibility that a species evolved in Vanuatu and then dispersed to the west cannot be discounted. The extra-Vanuatuan distribution of the indigenous, non-endemic species is given in Table 1. Of these twelve species, seven also occur in the Solomon Islands with five of these extending to New Guinea, four also occur in Fiji, and one, S. clusiifolium, also occurs in Polynesia. The remaining species, $S$. malaccense, occurs widely in the Malesian-southwest $\mathrm{Pacific}$ region but its natural range is probably New Guinea and Australia (Craven unpubl.). This species is widely cultivated and probably represents an example of early human introduction to the southwest Pacific islands and to central-western Malesia. The two non-indigenous species, $S$. cumini and $S$. jambos are relatively recent introductions to Vanuatu and have there naturalised. Interestingly, there appear to be no species shared with New Caledonia and given the proximity of the latter to Vanuatu this is surprising. The only link with New Caledonia seems to be sect. Piliocalyx, a taxon restricted to New Caledonia (c. 20 endemic species), Vanuatu (one endemic species) and Fiji (one endemic species). Within Vanuatu, some aspects of the distribution of the indigenous species may be noted. The distribution of each species by island is given in tabular form in Table 2 and from the map of the archipelago (Map 1) the spatial relationships of these islands can be determined. As the floristic exploration of Vanuatu is far from complete it is not possible to be definitive but nonetheless some comments can be made. Vanuatu endemics may be restricted to a single island ( $S$. aneityense) or widely distributed (S. kajewskii); this may reflect differences in dispersibility, soil tolerance and/or relative evolutionary age. Of the non-endemic species, S. clusiifolium and S. tierneyanum are widespread but $S$. gracilipes and $S$. seemannii each are known from a single island and it may be that the last two have relatively recently been dispersed to Vanuatu. Several islands have a relatively high number of species, e.g., Aneityum, Espiritu Santo, Efate, but this does not seem to be a function of size alone as Aneityum is small relative to the other two named islands and there may be other factors responsible. 


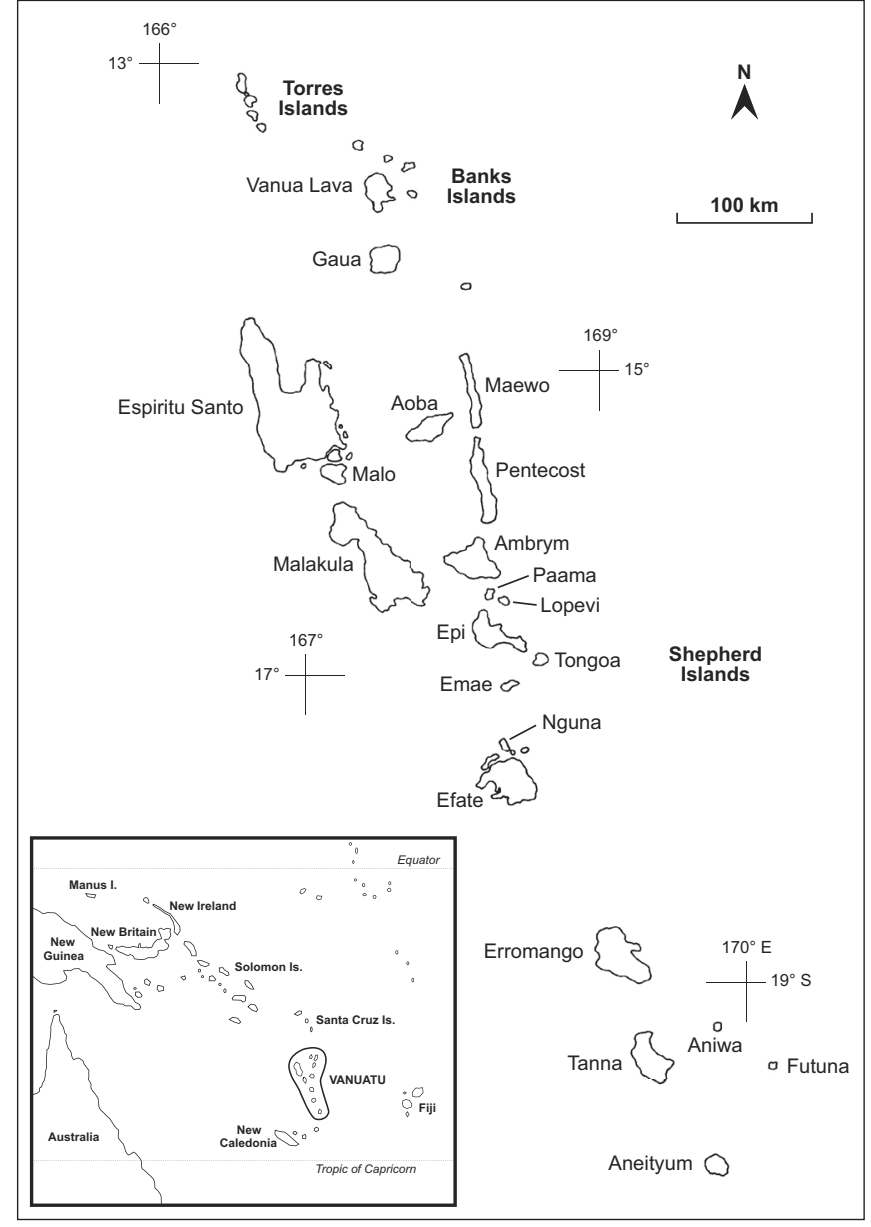

Map 1 Map of the Vanuatu archipelago.

\section{Morphological terminology}

The morphological terminology used here in the keys and descriptions is more or less in accordance with those used by authors in other regions. Most of the terms are well known but there are a few that need to be mentioned.

Anthopodium - internode between the flower(s) and the penultimate node of the inflorescence axis bearing the flowers (Briggs \& Johnson 1977).

Calyptrate calyx - flowers with a cap formed from the perianth. The calyptra may be formed from the fused sepals and is then circumscissile at anthesis, or it may be formed from the strongly coherent (but remaining free) petals that are caducous at anthesis and fall as a single unit (Briggs \& Johnson 1977).
Filament - is the male reproductive part of a plant topped by the anther together forming the stamen. It is free for most of the Syzygium species whilst it is physically fused at the base for others (Briggs \& Johnson 1977).

Hypanthium - floral structure that is the fusion of the sepals, petals and stamen forming a cuplike or tubular extension of a flower. The stipe in the hypanthium is part of the pedicel/ hypopodium (Briggs \& Johnson 1977).

Hypopodium - the lowerbase or the lowermost division of the internode between the flower(s) and the penultimate node of the inflorescence axis bearing the flower(s) (Briggs \& Johnson 1977).

Inflorescences - cluster of flowers arranged on a stem that is composed of a main branch or a complicated arrangement of branches spanned (Briggs \& Johnson 1977). The width of inflorescence is the total length in which the lateral axes spans.

Intrusive tissue - seed structure containing branching vascular tissue that is continuous with the axile vascular strand in the flower and provides an extensive surface area for the possible diffusion of food into the developing embryo (Hartley \& Craven 1977).

Open and closed venation - degree of development of tertiary veins (Hartley \& Perry 1973). In leaves with open venation the tertiary veins are not as well developed as the secondary and do not reach the intramarginal veins as do the secondary veins. In leaves with closed venation the tertiary veins are as well developed as the secondary veins. In leaves with closed venation, the tertiary veins are as well developed as the secondary veins and extend to the intramarginal vein. In open venation, the veins are more than $10 \mathrm{~mm}$ apart. In closed venation the veins are less than $10 \mathrm{~mm}$ apart.

\section{TAXONOMY}

\section{Syzygium Gaertn.}

Syzygium Gaertn., Fruct. 1 (1788) 166, t. 33. - Type: Syzygium caryophyllaceae Gaertn.

Tree or shrub glabrous throughout. Leaves opposite; lamina margin entire; primary, secondary and tertiary venation distinctly different or secondary and tertiary venation generally similar with all or nearly all tertiary veins joining the intramarginal vein; primary vein (midrib) abaxially rounded, prominulous, adaxially impressed; stipules absent. Flower sometimes calyptrate, sepals free or fused into a circumscissile calyptra, always not accrescent, petals distinctly free and deciduous or coherent into a caducous calyptrate. Stamens many, filaments free or fused proximally into phalanges; anther sacs dorsifixed, parallel, dehiscing by longitudinal slits. Stigma punctiform. Fruit a 1 -seeded berry. Seed sometimes with intrusive tissue interlocking the cotyledons.

Table 1 Extra-Vanuatuan distribution of indigenous Syzygium species.

\begin{tabular}{|c|c|c|c|c|c|c|c|c|}
\hline Species & South East Asia & $\begin{array}{l}\text { Malesia } \\
\text { (excl. New } \\
\text { Guinea) }\end{array}$ & Australia & $\begin{array}{l}\text { New Guinea } \\
\text { (incl. Bismark } \\
\text { archipelago) }\end{array}$ & Solomon Islands & New Caledonia & Fiji & Polynesia \\
\hline S. clusiifolium & & & & & & & & $x$ \\
\hline S. gracilipes & & & & & & & $x$ & \\
\hline S. insulare & & & & $x$ & $x$ & & & \\
\hline S. malaccense & cultivated & $x$ & $x$ & $x$ & $x$ & $x$ & $x$ & \\
\hline S. myriadenum & & & & & $x$ & & & \\
\hline S. nidie & & & & & & & $x$ & \\
\hline S. onesimum & & & & & $x$ & & & \\
\hline S. richii & & & & & & & $x$ & $x$ \\
\hline S. samarangense & cultivated & $x$ & & $x$ & $x$ & & $x$ & \\
\hline S. seemannii & & & & & & & $x$ & \\
\hline S. subcorymbosum & & & & $x$ & $x$ & & & \\
\hline S. tierneyanum & & & $x$ & $x$ & $x$ & & & \\
\hline
\end{tabular}




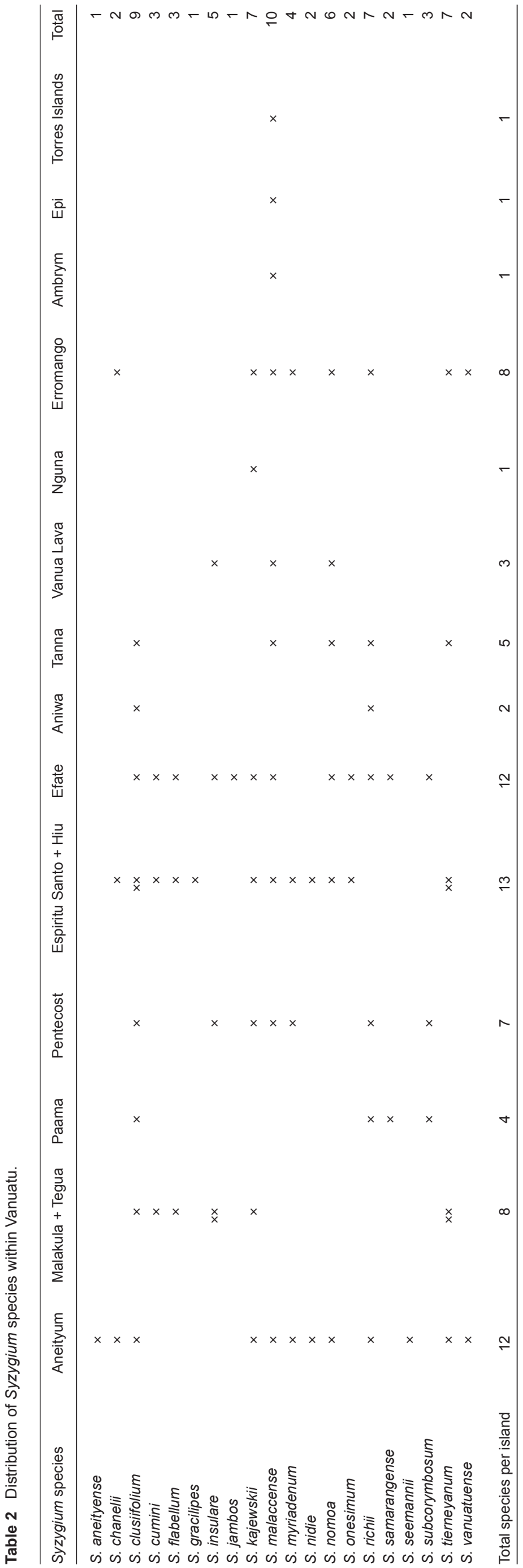

\section{IDENTIFICATION KEY TO THE SPECIES OF SYZYGIUM IN VANUATU BASED ON FLOWERING MATERIAL}

1. Calyx calyptrate . . . . . . . . . . . . . 2

1. Calyx free. . . . . . . . . . . . . . . 3

2. Hypanthium narrowly obconic or campanulate, c. 4 by 3 $\mathrm{mm} \ldots \ldots \ldots \ldots \ldots \ldots \ldots \ldots . . .2$. S. chanelii

2. Hypanthium subspheroidal or conical to narrowly oblong, c. 12 by $5 \mathrm{~mm}$. . . . . . . . . . . . 17. S. seemannii

3. Hypanthium more than $20 \mathrm{~mm}$ long ......... 4

3. Hypanthium less than or equal to $20 \mathrm{~mm}$ long . . . . . 8

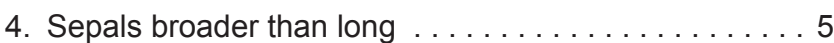

4. Sepals equally long as wide, c. 12 by $13 \mathrm{~mm}$; hypanthium c. $25 \mathrm{~mm}$ long . . . . . . . . . . . . 5. 5. flabellum

5. Main inflorescence lax and pendulous; hypopodium more than $20 \mathrm{~mm}$ long . . . . . . . . . . . . . 6. S. gracilipes

5. Main inflorescence not lax or pendulous; hypopodium up to $20 \mathrm{~mm}$ long . . . . . . . . . . . . . . . . . 6

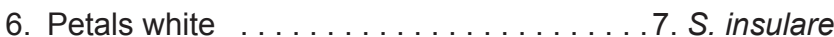

6. Petals not white $\ldots \ldots \ldots \ldots \ldots \ldots \ldots \ldots \ldots$

7. Filament pink or red; hypanthium clavate to campanulate, c. 30 by $10 \mathrm{~mm}$; sepals c. 4 by $6 \mathrm{~mm}$ 10. S. malaccense

7. Filament yellow; hypanthium obconical, c. 28 by $20 \mathrm{~mm}$; sepals c. 6 by $10 \mathrm{~mm} \mathrm{...} \mathrm{.} \mathrm{.} \mathrm{.} \mathrm{.} \mathrm{.} \mathrm{.} \mathrm{.} \mathrm{.} \mathrm{15.} \mathrm{S.} \mathrm{richii}$

8. Hypanthium less than or equal to $10 \mathrm{~mm}$ long . . . . . . 9

8. Hypanthium more than $10 \mathrm{~mm}$ long . . . . . . 15

9. Inflorescence bract persistent, up to $0.5 \mathrm{~mm}$ long. ..... $\ldots \ldots \ldots \ldots \ldots \ldots \ldots \ldots \ldots \ldots$. S. aneityense

9. Inflorescence bract not persistent . . . . . . . . . 10

10. Hypanthium c. 4 by $2 \mathrm{~mm}$; bracts caducous . . . . . . $\ldots \ldots \ldots \ldots \ldots \ldots \ldots \ldots$. . . . . . . . . . . . . . . . . .

10. Hypanthium up to 10 by $8 \mathrm{~mm}$; bracts deciduous . . . 11

11. Less than 1-3 flowers per anthopodium . . . . . . . . . 12

11. More than 3 flowers per anthopodium . . . . . . . 13

12. Hypanthium obconic; sepals c. $1 \mathrm{~mm}$ long 13. S. nomoa

12. Hypanthium clavate; sepals $0.5 \mathrm{~mm}$ long . . . . . . . . . . . . . . . . . . . . . . . 18. S. subcorymbosum

13. Inflorescence 9 by $12 \mathrm{~cm}$ or larger; hypopodium more than $2 \mathrm{~mm}$ long . . . . . . . . . . . . . . . . . 14

13. Inflorescence c. 7 by $5 \mathrm{~cm}$; hypopodium up to $2 \mathrm{~mm}$ long $\ldots \ldots \ldots \ldots \ldots \ldots \ldots \ldots$ 4. S. cumini

14. Hypanthium c. 8 by $3 \mathrm{~mm}$, stipe $2 \mathrm{~mm}$ long; petals c. 3 by

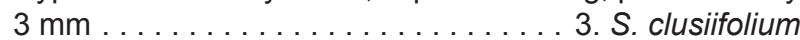

14. Hypanthium c. 10 by $8 \mathrm{~mm}$, stipe up to $4 \mathrm{~mm}$ long; petals less than 1 by $2 \mathrm{~mm}$... . . . . . . . . . 9. 9. kajewskii

15. Hypanthium stipitate . . . . . . . . . . . . 16

15. Hypanthium not stipitate $\ldots \ldots \ldots \ldots \ldots \ldots \ldots \ldots 18$

16. Sepals c. 8 by $8 \mathrm{~mm}$... . . . . . 16. S. samarangense

16. Sepals wider than long . . . . . . . . . . . . . 17

17. Sepals c. 4 by $11 \mathrm{~mm}$.............. 8. S. jambos

17. Sepals up to 2 by $8 \mathrm{~mm} \ldots \ldots \ldots$ 19. S. tierneyanum

18. Hypanthium narrowly oblong, c. 17 by $5 \mathrm{~mm}$; sepals c. 1 by $3 \mathrm{~mm} \ldots \ldots \ldots \ldots \ldots \ldots$ 11. S. myriadenum

18. Hypanthium campanulate or funnel like, c. 14 by $10 \mathrm{~mm}$; sepals c. 2 by $4 \mathrm{~mm}$. . . . . . . . . . . . 12. S. nidie

\section{IDENTIFICATION KEY TO THE SPECIES OF SYZYGIUM} IN VANUATU BASED ON VEGETATIVE FEATURES ONLY

1. Vegetative branchlet quadrangular . . . . . . . . 2

1. Vegetative branchlet terete . . . . . . . . . . 5

2. Vegetative branchlet winged; lamina c. 24 by $13 \mathrm{~cm}$; leaf base cordate, apex rounded to acute, margin undulate; 
secondary veins 10-15 each side of primary vein, c. $4 \mathrm{~cm}$ apart; petiole c. $12 \mathrm{~mm}$ long ............ 15. S. richii

2. Vegetative branchlet not winged . . . . . . . . 3

3. Secondary veins more than 20 each side of primary vein

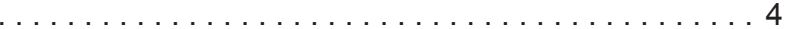

3. Secondary veins less than 20 , c. 14 each side of primary vein, c. $8 \mathrm{~mm}$ apart; intramarginal vein strongly arched, c. $2.5 \mathrm{~mm}$ from lanina midpoint; lamina c. 14 by $3.4 \mathrm{~cm}$; leaf base cuneate, apex acute, acumen acute, margin flat, texture coriaceous; petiole 4-6 mm long . . 8. S. jambos

4. Lamina up to 23.5 by $7.2 \mathrm{~cm}$; leaf base cuneate, apex acute or sometimes rounded; secondary veins c. $5 \mathrm{~mm}$ apart; intramarginal veins $2-4 \mathrm{~mm}$ from lamina midpoint; petiole c. $2 \mathrm{~cm}$ long . . . . . . . . . . . . . 11. S. myriadenum

4. Lamina up to 15.6 by $5.8 \mathrm{~cm}$; leaf base attenuate or cuneate, apex retuse or rounded; secondary veins c. $2 \mathrm{~mm}$ apart; intramarginal veins c. $2 \mathrm{~mm}$ from lamina midpoint; petiole c. $15 \mathrm{~mm}$ long ... . . . . . . . . . . . . 13. S. nomoa

5. Lamina $20 \mathrm{~cm}$ long or longer . . . . . . . . . . . . 6

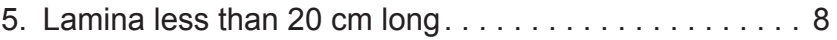

6. Leaf base cuneate or retuse $\ldots \ldots \ldots \ldots \ldots \ldots 7$

6. Leaf base truncate, apex acute, acumen flat, margin slightly undulate, texture chartaceous; secondary veins 8 each side of primary vein, $45 \mathrm{~mm}$ apart; intramarginal veins absent; petiole up to $3.5 \mathrm{~cm}$ long; lamina c. 28 by $17 \mathrm{~cm} \ldots \ldots$.

5. S. flabellum

7. Secondary veins $11-18 \mathrm{~mm}$ apart; intramarginal veins $1-6 \mathrm{~mm}$ from lamina midpoint; lamina up to 25 by $7.9 \mathrm{~cm}$; leaf base cuneate, apex acute or acuminate, acumen flat, margin slightly undulate; secondary veins $8-13$ each side of primary vein; petiole c. $9 \mathrm{~mm}$ long 10. S. malaccense

7. Secondary veins c. $24 \mathrm{~mm}$ apart; intramarginal veins c. $9 \mathrm{~mm}$ from lamina midpoint; lamina c. 26 by $10 \mathrm{~cm}$; leaf base cuneate or retuse, apex acuminate, acumen flat or recurved, margin undulate; secondary veins c. 13 each side of primary vein; petiole c. $10 \mathrm{~mm}$ long 7 . S. insulare

8. Secondary veins more than 20 each side of primary vein . . . . . . . . . . . . . . . . . . . . . . 9

8. Secondary veins less than 20 each side of primary vein

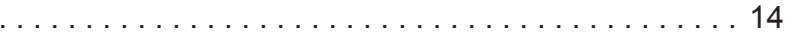

9. Leaf texture chartaceous, margin undulate, acumen flat or recurved, base cuneate or attenuate; lamina up to 10.5 by $4.9 \mathrm{~cm}$; secondary veins c. $3 \mathrm{~mm}$ apart; intramarginal veins $18-30 \mathrm{~mm}$ from lamina midpoint . 9. S. kajewskii

9. Leaf texture coriaceous . . . . . . . . . . . . 10

10. Leaf base attenuate. . . . . . . . . . . . . . . 11

10. Leaf base cuneate, apex acuminate, acumen flat, margin flat to undulate; lamina c. 16 by $4 \mathrm{~cm}$; secondary veins 5-8 $\mathrm{mm}$ apart; intramarginal veins c. $2 \mathrm{~mm}$ from lamina midpoint; petiole c. $25 \mathrm{~mm}$ long ....... 4. S. cumini

11. Leaf apex acuminate, margin undulate . . . . . . 12

11. Leaf apex acute, margin flat, base attenuate; lamina up to 8 by $4.2 \mathrm{~cm}$; secondary veins c. $4 \mathrm{~mm}$ apart; intramarginal veins c. $2 \mathrm{~mm}$ from lamina midpoint; petiole c. $15 \mathrm{~mm}$ long . . . . . . chanelii

12. Lamina more than or equal to $8 \mathrm{~cm} \ldots \ldots \ldots 13$

12. Lamina less than $8 \mathrm{~cm}$, c. 6.5 by $3.1 \mathrm{~cm}$; leaf base attenuate, apex acuminate, acumen recurved, margin undulate, texture coriaceous; secondary veins more than 20 each side of primary vein, c. $1.5 \mathrm{~mm}$ apart; intramarginal vein absent, c. $1 \mathrm{~mm}$ from lamina midpoint; petiole c. $15 \mathrm{~mm}$ long . . . . . . . . . n . . . . . . . 12.

13. Lamina up to 8 by $3.3 \mathrm{~cm}$; petiole c. $13 \mathrm{~mm}$ long . . . . . . . . . . . . . . . . . . . . . . . . 14. S. onesimum
13. Lamina up to 8.6 by $3.7 \mathrm{~cm}$; petiole c. $10 \mathrm{~mm}$ long. . . . 18. S. subcorymbosum

14. Lamina length more than or equal to $12 \mathrm{~cm} \ldots \ldots 15$

14. Lamina length less than $12 \mathrm{~cm} \ldots \ldots \ldots \ldots \ldots 18$

15. Lamina more than or equal to $7 \mathrm{~cm}$ wide $\ldots \ldots \ldots 16$

15. Lamina less than $7 \mathrm{~cm}$ wide $\ldots \ldots \ldots \ldots \ldots \ldots 17$

16. Lamina up to 15 by $7.7 \mathrm{~cm}$; leaf base cordate or cuneate, apex acute or short acuminate, acumen flat or recurved, margin flat or recurved; secondary veins 7-14 each side of primary vein, c. $11 \mathrm{~mm}$ apart; petiole subsessile to sessile c. $3 \mathrm{~mm}$ long . . . . . . . . . . 16. S. samarangense

16. Lamina up to 15 by $9.6 \mathrm{~cm}$; leaf base cuneate, apex acute, acumen flat, margin slightly undulate; secondary veins 15-18 each side of primary vein, c. $10 \mathrm{~mm}$ apart; petiole c. $15 \mathrm{~mm}$ long ............... 3. S. clusiifolium

17. Lamina c. 18 by $6 \mathrm{~cm}$; leaf base cordate, apex acute, acumen flat, margin flat; secondary veins c. 13 each side of primary vein, c. $18 \mathrm{~mm}$ apart; intramarginal veins c. $5 \mathrm{~mm}$ from lamina midpoint; petiole c. $10 \mathrm{~mm}$ long.

6. S. gracilipes

17. Lamina up to 15 by $6.6 \mathrm{~cm}$; leaf base cuneate sometimes attenuate, acumen recurved, margin flat or undulate; secondary veins 7-11 each side of primary vein, $18-28 \mathrm{~mm}$ apart; intramarginal veins absent; petiole $6-15 \mathrm{~mm}$ long

19. S. tierneyanum

18. Secondary veins more than or equal to $2 \mathrm{~cm}$ apart .. 19

18. Secondary veins less than $2 \mathrm{~cm}$ apart, up to $1.8 \mathrm{~cm}$ apart; lamina up to 11 by $5.5 \mathrm{~cm}$; leaf base attenuate or cuneate, apex cuspidate, acumen recurved, margin flat; secondary veins $c .7$ each side of primary vein; intramarginal veins strongly arched; petiole $6-15 \mathrm{~mm}$ long

20. S. vanuatuense

19. Secondary veins c. $5 \mathrm{~mm}$ apart, c. 11 each side of primary vein; intramarginal veins c. $1 \mathrm{~mm}$ from lamina midpoint; lamina up to 7 by $3.5 \mathrm{~cm}$; leaf base attenuate or cuneate, apex acuminate, acumen undulate, margin slightly undulate; petiole c. $10 \mathrm{~mm}$ long .........17. S. seemannii

19. Secondary veins $5-8 \mathrm{~mm}$ apart, $7-11$ each side of primary vein; intramarginal veins $11-18 \mathrm{~mm}$ from lamina midpoint; lamina up to 11.5 by $5 \mathrm{~cm}$; leaf base cuneate, apex acuminate, acumen flat, margin slightly undulate; petiole $5-8 \mathrm{~mm}$ long ............... aneityense

\section{Syzygium aneityense Guillaumin}

Syzygium aneityense Guillaumin (1931) 256. — Typus: Kajewski 846 (lecto $\mathrm{P}$, here designated; iso K), Vanuatu, Tafea Province, Aneityum, Anelgauhat Bay, 335 m, 2 Mar. 1929.

Tree up to $15 \mathrm{~m}$ tall. Vegetative branchlets terete, up to $3 \mathrm{~mm}$ diam; bark dull, smooth, not glandular or verrucose, persistent. Leaf lamina $5.5-11.5$ by $2.2-5 \mathrm{~cm}$, elliptic; base symmetric, cuneate; apex acuminate, acumen flat; margin flat; chartaceous; drying greenish brown above; primary vein (midrib) less than $1 \mathrm{~mm}$ wide; secondary veins closed, 7-11 each side of primary vein, 5-8 $\mathrm{mm}$ apart; intramarginal vein strongly arched, 11-18 $\mathrm{mm}$ from the margin at the lamina midpoint; secondary intramarginal vein weakly arched; tertiary intramarginal vein absent or present, weakly arched; oil dots present, not visible to the unaided eye through transmitted light, small, sparse. Petiole 5-8 mm long, adaxially slightly grooved. Inflorescence terminal or axillary, cymose panicle; up to 8 by $12 \mathrm{~cm}, 1-3$ flowers per anthopodium; hypopodium c. $5 \mathrm{~mm}$ long; main inflorescence axis $1 \mathrm{~mm}$ wide, terete, dull, smooth; bracts persisting, up to $0.5 \mathrm{~mm}$ long. Hypanthium stipitate, stipe 1-3 mm long; obconic or broadly clavate, c. 10 by $5 \mathrm{~mm}$, dull, not visibly gland dotted, minutely wrinkled. Sepals $4,0.2-0.4$ by $1-1.5 \mathrm{~mm}$, coherent, 
persistent. Petals not seen. Stamens many, more than 50, up to $10 \mathrm{~mm}$ long; filaments free, yellow; anther sacs circular. Style up to $12 \mathrm{~mm}$ long. Fruit not seen.

Distribution \& Ecology - Vanuatu (Tafea province: Aneityum). Syzygium aneityense is common in lowland rainforest at elevations up to c. $500 \mathrm{~m}$ asl.

Vernacular name - Nomogheo (Aneityum).

Uses - The timber is a hardwood but has no known specific use.

Notes - 1. Flowers have been recorded from March to June. The fruiting period is unknown.

2. Syzygium aneityense can be misidentified as S. kajewskii because of superficial similarities in the foliage. However, these two species can be distinguished on leaf size, shape of the leaf base, petiole length, tertiary venation type, hypanthium shape and sepal size. In $S$. aneityense the leaf is $5.5-11$ by $2.2-5$ $\mathrm{cm}$, the leaf base is cuneate, the petiole c. $5-8 \mathrm{~mm}$ long, the venation is open, the hypanthium is obconic or broadly clavate, and the sepals are small to almost inconspicuous $0.2-0.4 \mathrm{~mm}$ long. For S. kajewskii, the leaves are $4.5-10.5$ by $2.3-4.9 \mathrm{~cm}$, the leaf base is cuneate or attenuate, the petiole up to $27 \mathrm{~mm}$ long, the venation is closed, the hypanthium is obconical or campanulate and the sepals are 1 by $2 \mathrm{~mm}$.

3. When describing S. aneityense, Guillaumin (1931) cited only one collection, Kajewski 846, but did not designate a particular specimen as holotype. In accordance with Recommendation 9A.4 of the International Code of Botanical Nomenclature (ICBN; McNeill et al. 2012), the specimen deposited in Guillaumin's home institution, $P$, is considered to be the type and is designated lectotype above.

\section{Syzygium chanelii S.H.Tuiwawa \& Craven, sp. nov. - Fig. 1}

A S. concinno (A.C.Sm.) Craven \& Biffin alabastris maturis late turbinatis, 4-5 mm longis, 2.4-4 mm latis, staminibus numerosioribus (c. 50-60) et filamentis 1-1.8 mm longis, et stylo 1-1.5 mm longo differt. - Typus: Gowers NH157 (holo K), Vanuatu, 1974

Etymology. This species is named in honour of Mr. Chanel Sam, Curator of the Vanuatu National Herbarium (PVNH) in Port Vila. Mr. Sam has an excellent knowledge of the flora of Vanuatu and has published on economic plants of the Southwest Pacific region (Walter \& Sam 2002).

Tree up to $30 \mathrm{~m}$ tall. Vegetative branchlets terete, up to $5 \mathrm{~mm}$ diam; bark dull, smooth, not glandular or verrucose, persistent. Leaf lamina up to 8 by $4.2 \mathrm{~cm}$, elliptic; base symmetric, attenuate; apex acute, acumen recurved; margin flat; coriaceous; drying reddish brown above; primary vein (midrib) $1 \mathrm{~mm}$ wide; secondary veins closed, more than 20 each side of primary vein, c. $4 \mathrm{~mm}$ apart; intramarginal vein strongly arched, c. $2 \mathrm{~mm}$ from the margin at the lamina midpoint; secondary and tertiary intramarginal vein absent; oil dots present, not visible to the unaided eye in transmitted light, small, dense. Petiole c. 15 by $1 \mathrm{~mm}$, adaxially strongly grooved. Inflorescence terminal, cymose panicle, $5.5-7.5$ by $3-6 \mathrm{~cm}$, c. $5-7$ flowers per anthopodium; hypopodium c. $3 \mathrm{~mm}$ long; main inflorescence axis $1 \mathrm{~mm}$ wide, terete, dull, smooth; bracts deciduous, less than $0.5 \mathrm{~mm}$ long. Hypanthium stipitate, stipe up to $1.5 \mathrm{~mm}$ long; narrowly obconic or campanulate, c. 4 by $3 \mathrm{~mm}$, dull, not visibly dotted glands, minutely wrinkled. Sepals fused into a calyptra, falling at anthesis. Petals not seen. Stamens many, more than 50 , outermost stamens $1 \mathrm{~mm}$ long; filament free, colour not seen; anther sacs circular. Style up to $1.5 \mathrm{~mm}$ long. Fruit white when ripe, smooth, spheroidal, up to 2 by $2 \mathrm{~cm}$. Seed with an intrusive tissue interlocking the cotyledons.

Distribution \& Ecology — Vanuatu (Sanma province: Espiritu Santo; Tafea province: Aneityum, Erromango). The species occurs in kauri forest up to $180 \mathrm{~m}$ asl.

Vernacular name - Nette (Aneityum).
Uses - The species is reported to provide excellent timber.

Notes - 1. Flowers have been recorded in June and fruit in November.

2. Within Vanuatu, S. chanelii is readily distinguished by the combination of a calyptrate calyx and a hypanthium c. $4 \mathrm{~mm}$ long. In fruit it is unique among the Vanuatu species for which fruit are known in that the seed possesses an intrusive tissue that interlocks the cotyledons.

3. Differs from S. concinno (A.C.Sm.) Craven \& Biffin in the following features: mature flower buds broadly turbinate and $4-5$ by $2.4-4 \mathrm{~mm}$, more numerous stamens (c. $50-60$ ), filaments $1-1.8 \mathrm{~mm}$ long and style $1-1.5 \mathrm{~mm}$ long.

\section{Syzygium clusiifolium (A.Gray) Müll.Berol.}

Syzygium clusiifolium (A.Gray) Müll.Berol. (1858) 839. — Eugenia clusiaefolia A.Gray (in Gray \& Wilkes 1854) 528. - Typus (fide Whistler (1988) 178, as holotype): U.S. Expl. Exped. s.n. (lecto US n.v.; iso GH (fragm.) n.v., K n.v.), Samoa, Tutuila and Savaii, on rocks near the sea, 1839.

Syzygium neepau Guillaumin (1931) 257, syn. nov. — Typus: Wilson 973 (holo P; iso BRI, K), Vanuatu, Tafea Province, Aneityum, Anelgauhat Bay, $657 \mathrm{~m}$, Sept. 1929

Tree up to $20 \mathrm{~m}$ tall. Vegetative branchlets terete to terminally compressed, up to $4 \mathrm{~mm}$ diam; bark dull, furfuraceous, not glandular or verrucose, flaking. Leaf lamina up to 15 by $7.6-9.6$ $\mathrm{cm}$, elliptic; base symmetric, cuneate; apex acute, acumen flat; margin slightly undulate; coriaceous; drying reddish brown above; primary vein $1 \mathrm{~mm}$ wide; secondary veins closed, 1518 each side of primary vein, $10 \mathrm{~mm}$ apart; intramarginal vein strongly arched, $2.5-4 \mathrm{~mm}$ from the margin at the lamina midpoint; secondary intramarginal vein weakly arched; tertiary intramarginal vein absent; oil dots present, not visible to the unaided eye in transmitted light, small, dense. Petiole c. 15 $\mathrm{mm}$ long; adaxially strongly grooved. Inflorescence among the leaves or cauliflorous, cymose panicle; c. 26 by $25 \mathrm{~cm}$, c. 3-9 flowers per anthopodium; hypopodium up to $10 \mathrm{~mm}$ long; main inflorescence axis $3 \mathrm{~mm}$ wide, terete, dull, smooth; bracts deciduous, $0.5-1 \mathrm{~mm}$ long. Hypanthium stipitate, stipe $2 \mathrm{~mm}$ long; obconic, up to 8 by $3 \mathrm{~mm}$, dull, not visibly gland dotted, striate to slightly wrinkled. Sepals 4 , up to 1 by $3 \mathrm{~mm}$, semicircular, coherent, persistent. Petals 4, caducous, coherent, circular, up to 3 by $3 \mathrm{~mm}$, visibly gland dotted; margin entire. Stamens many, more than 50 , outermost stamens up to $8 \mathrm{~mm}$ long; filaments free, yellow; anther sacs oblong or elliptic. Style up to $5 \mathrm{~mm}$ long. Fruit pink to red when ripe, smooth, pyriform, up to 2 by $1.3 \mathrm{~cm}$.

Distribution \& Ecology - Vanuatu (Malampa province: Malakula, Paama; Penama province: Pentecost; Sanma province: Espiritu Santo; Shefa province: Efate; Tafea province: Aneityum, Aniwa, Tanna. Torba province: Hiu). Syzygium clusiifolium also occurs in Polynesia in Samoa, Uvea, Tonga and Futuna (Whistler 1988). In Vanuatu, the species occurs predominantly on the coast and in lowland rainforest below $300 \mathrm{~m}$ asl.

Vernacular names - Neepau (Aneityum); naavakhsisiel (Malakula).

Uses - The timber is hard and is used for firewood; roof framing on houses and canoe masts. The fruit is edible. There is an association between this tree and the cultivation of yams (Dioscorea sp.) but it is unclear at which growth or developmental phase $S$. clusiifolium becomes a useful indicator for favorable seasons to cultivate.

Notes - 1. Flowers have been recorded between September and December, and fruit in February.

2. Syzygium clusiifolium is absent in Fiji, Papuasia and New Caledonia but occurs quite widely in Polynesia where it is also a cultivated plant (Whistler 1988). Its occurrence in Vanuatu may result from an early introduction by man, especially as the 


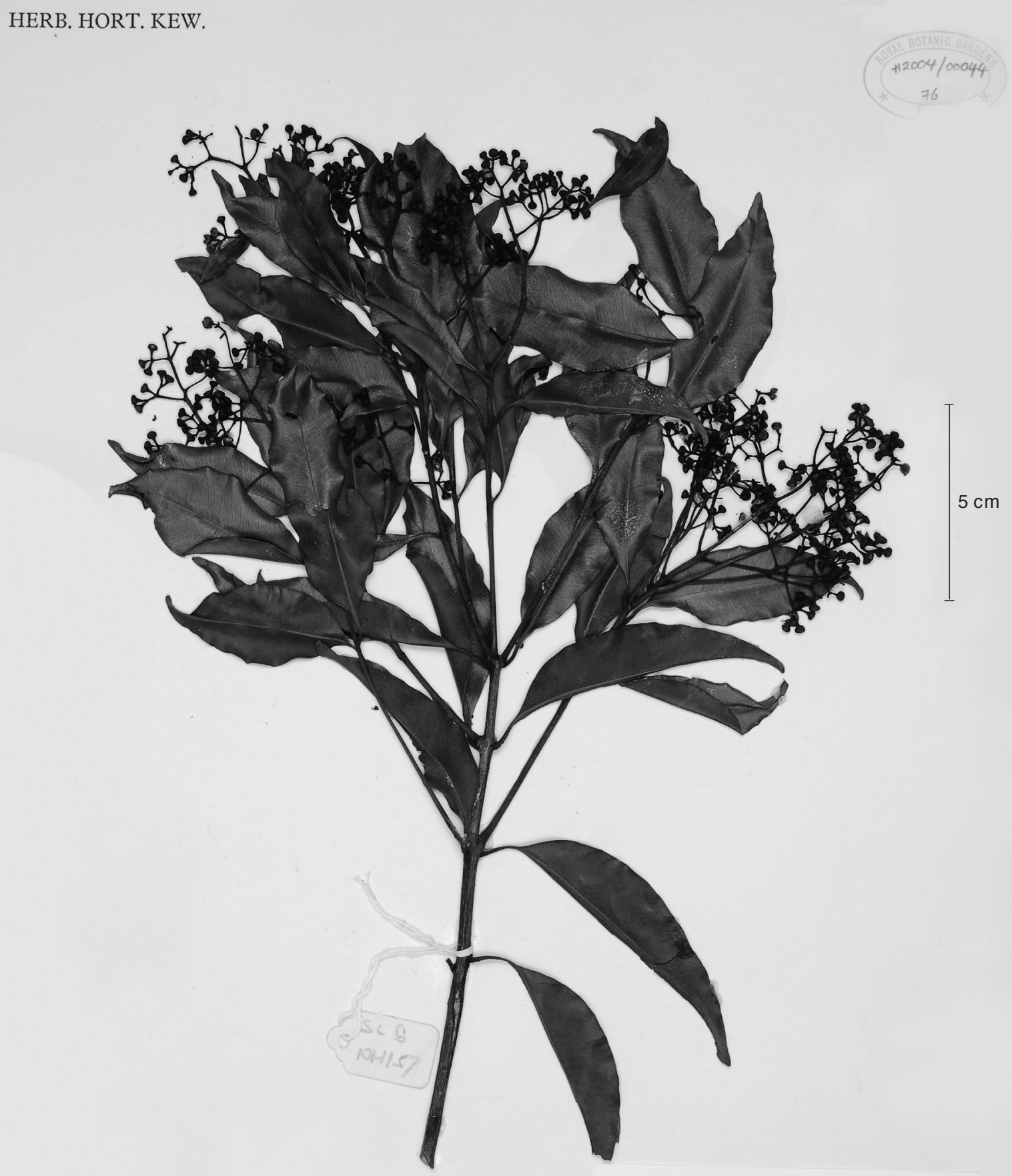

Syzygium chanelii Tuiwawa nolotype

determinavit S.H. Tuiwawa 2008

Piliocalyx sp. nov. (?) aff. concinnus

A. C.Sm.

Determined by A. C. Smith

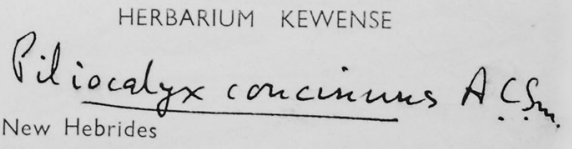

1974 Sheila Gowers $\mathrm{NH} / 57$

Fig. 1 Holotype of S. chanelii S.H.Tuiwawa \& Craven. 
fruit is edible and the plant is associated with the cultivation of taro.

3. The species is distinctive in leaf size and shape but it could be mistaken for $S$. malaccense. These two species can be distinguished by the type of venation, petiole length and inflorescence size. In S. clusiifolium, the secondary veins are closed, the petiole c. $15 \mathrm{~mm}$ long and the inflorescence c. 26 by $25 \mathrm{~cm}$. In $S$. malaccense, the secondary veins are open, the petiole is $6-9 \mathrm{~mm}$ long and the inflorescence c. 6 by $3 \mathrm{~cm}$.

3. Whistler (1988) cited the US specimen, U.S. Expl. Exped. s.n. (Tutuila and Savaii, on rocks near the sea, 1839), as holotype of Eugenia clusiaefolia. However, Gray (Gray \& Wilkes 1854) did not designate a holotype specimen and the US material is more appropriately regarded as the lectotype of the name.

4. When describing S. neepau, Guillaumin (1931) cited only one collection, Wilson 973 , but did not designate a particular specimen as holotype. In accordance with Recommendation 9A.4 of the ICBN (McNeill et al. 2012), the specimen deposited in Guillaumin's home institution, $\mathrm{P}$, is considered the holotype.

\section{Syzygium cumini (L.) Skeels}

Syzygium cumini (L.) Skeels (1912) 25. — Myrtus cumini L. (1753) 560. Eugenia cumini (L.) Druce (1914) 418. - Typus (fide Kostermans 1981, Verdcourt 2001): Herb. Hermann 1: 45, No. 185, right specimen (lecto BM n.v.), Sri Lanka.

Tree up to $30 \mathrm{~m}$ tall. Vegetative branchlets terete, up to $3 \mathrm{~mm}$ diam; bark dull, slightly striated, not glandular or verrucose, persistent. Leaf lamina c. 16 by $7 \mathrm{~cm}$, narrowly elliptic to oblong; base symmetric, cuneate; apex longly acuminate, acumen flat; margin flat to undulate; coriaceous; drying reddish brown above; primary vein (midrib) $1 \mathrm{~mm}$ wide; secondary veins closed, more than 20 each side of primary vein, $5-8 \mathrm{~mm}$ apart; intramarginal vein strongly arched, up to $2 \mathrm{~mm}$ from the margin at the lamina midpoint; secondary and tertiary intramarginal vein absent; oil dots present, not visible to the unaided eye in transmitted light, small, dense. Petiole c. $25 \mathrm{~mm}$ long; adaxially strongly grooved. Inflorescence terminal-axillary or cauliflorous; corymbose panicle; up to 7 by $5 \mathrm{~cm}, 6-9$ flowers (closely clustered) per anthopodium; hypopodium up to $2 \mathrm{~mm}$ long; main inflorescence axis $1 \mathrm{~mm}$ wide, terete, dull, slightly wrinkled; bracts deciduous, up to $0.5 \mathrm{~mm}$ long. Hypanthium stipitate, stipe c. $3 \mathrm{~mm}$ long; obconic to campanulate, c. 6 by $6 \mathrm{~mm}$, glossy, not visibly gland dotted, striated. Sepals 4 , up to 0.5 by $2 \mathrm{~mm}$, subcircular, persistent, free. Petals not seen. Stamens many, more than 50 , outermost stamens up to $6 \mathrm{~mm}$ long; filament white, free; anther sacs elliptic or circular. Style c. $3 \mathrm{~mm}$ long. Fruit pink to dark purple; smooth; plane; ellipsoid; up to 2.5 by $1.3 \mathrm{~cm}$.

Distribution \& Ecology — Vanuatu (Malampa province: Malakula; Sanma province: Espiritu Santo; Shefa province: Efate). Syzygium cumini is widely distributed in the Indomalesian region and is commonly cultivated in tropical regions. Its natural range may be India and Sri Lanka (Smith 1985). The species is naturalised in several countries, e.g., Fiji and New Caledonia, and potentially be adventive in Vanuatu.

Vernacular names - Scamon tree (SE coast of Malakula); esamilo (Espiritu Santo).

Uses - The fruits are edible but are usually used for making preserves. It is also a useful timber for construction (Smith 1985).

Notes - 1. Flowers have been recorded from December to January but fruit is reported to be borne throughout the year which suggests that flowering may be throughout the year also.

2. Syzygium cumini has fairly elegant and distinctive vegetative features as evidenced by the slender, elliptic leaves and straight petiole. On vegetative and inflorescence features, S. cumini is similar to S. kajewskii. Nevertheless, these two species are distinct in leaf texture, petiole straightness and in the density and number of flowers per peduncle. In S. cumini, the leaves are coriaceous, the petiole is straight and the inflorescences are closely clustered with 6-9 flowers per anthopodium. In S. kajewskii, the leaves are chartaceous, the petiole is distally somewhat curved, and the flowers are fewer with 3 per anthopodium.

\section{Syzygium flabellum S.H.Tuiwawa \& Craven, sp. nov.}

A S. richii (A.Gray) Merr. \& L.M.Perry ramulis teretis, lamina foliorum late ovata, majore (c. $28 \times 17 \mathrm{~cm}$ ), basi truncata, petiolis longioribus (c. $3.5 \mathrm{~cm}$ longis), et sepalis majoribus (c. $12 \times 13 \mathrm{~mm}$ ) differ. - Typus: Green RSNH1088 (holo K; iso P), Vanuatu, Efate, near Rentepao, E168²7', 14 July 1971.

Tree up to $20 \mathrm{~m}$ tall. Vegetative branchlets terete, $6 \mathrm{~mm}$ diam; bark dull, cracked, not glandular or verrucose, flaking. Leaf lamina c. 28 by $17 \mathrm{~cm}$, broadly ovate; base symmetric, truncate; apex acute, acumen flat; margin flat; chartaceous; drying reddish brown above; primary vein (midrib) stout, $2 \mathrm{~mm}$ wide; secondary veins open, 8 each side of primary vein, c. $45 \mathrm{~mm}$ apart; intramarginal vein absent; secondary and tertiary intramarginal vein absent; oil dots present, not visible to the unaided eye in transmitted light, small, sparse. Petiole up to 35 by 4 $\mathrm{mm}$, adaxially strongly grooved. Inflorescence below the leaves, simple dichasia, c. 4 by $6 \mathrm{~cm}$, up to 3 flowers per anthopodium; hypopodium up to $8 \mathrm{~mm}$ long; main inflorescence axis $3 \mathrm{~mm}$ wide, terete, dull, smooth to slight striate; bracts caducous, c. $2 \mathrm{~mm}$ long. Hypanthium white, stipitate, stipe $1 \mathrm{~mm}$ long; campanulate, c. 25 by $23 \mathrm{~mm}$, dull, not visibly gland dotted, smooth. Sepals 4, c. 12 by $13 \mathrm{~mm}$, semicircular, persistent, free. Petals c. 4 , deciduous, coherent, circular, c. 12 by $13 \mathrm{~mm}$, visibly gland dotted; margin entire. Stamens many, more than 50 , outermost stamens c. $20 \mathrm{~mm}$ long; filament free, colour not seen; anther sacs oblong. Style c. $30 \mathrm{~mm}$ long. Fruit not seen.

Distribution \& Ecology — Vanuatu (Malampa province: Malakula; Sanma province: Espiritu Santo; Shefa province: Efate). This species is endemic to Vanuatu where it occurs in coastal forest.

Vernacular names - Unknown.

Uses - Unknown.

Notes - 1. Flowers have been recorded in March and fruit in July.

2. Syzygium flabellum could be misidentified as S. richii because of the similarities in vegetative features and hypanthium; for a comparison between the two species see under the latter species.

3. The epithet flabellum is a noun in apposition and comes from the Latin flabellum, fan. The fan-shaped, often large leaves are a distinctive feature of this species.

4. Differs from $S$. richii in the following features: branchlets terete; leaf blade broadly ovate, larger (c. 28 by $17 \mathrm{~cm}$ ), base truncate, longer than the petiole; sepals larger (c. 12 by $13 \mathrm{~mm}$ ).

\section{Syzygium gracilipes (A.Gray) Merr. \& L.M.Perry}

Syzygium gracilipes (A.Gray) Merr. \& L.M.Perry (1942b) 78. - Eugenia gracilipes A.Gray (in Gray \& Wilkes 1854: 513). - Jambosa gracilipes (A.Gray) Müll.Berol. (1858) 849. - Typus (fide Smith (1985) 349, as holotype): U.S. Expl. Exped. s.n. (lecto US n.v.), Fiji.

Tree up to $7 \mathrm{~m}$ tall. Vegetative branchlets terete, c. $3 \mathrm{~mm}$ diam; bark dull, smooth to slightly cracked, persistent. Leaf lamina c. 18 by $6 \mathrm{~cm}$, lanceolate or elliptic; base symmetric, cordate; apex acute, acumen flat; margin flat; chartaceous; drying reddish brown above; primary veins (midrib) less than $1 \mathrm{~mm}$ wide; secondary veins open, c. 13 each of the primary vein, c. 18 
$\mathrm{mm}$ apart; intramarginal vein strongly arched, c. $5 \mathrm{~mm}$ from the margin at the lamina midpoint; secondary intramarginal vein weakly arched; tertiary intramarginal vein absent; oil dots present, not visible to the unaided eye in transmitted light, small, dense. Petiole c. $10 \mathrm{~mm}$ long; adaxially slightly grooved. Inflorescence terminal or axillary sometime below the leaves, cyme, up to 7 by $6.5 \mathrm{~cm}$, 3 flowers per anthopodium; hypopodium c. $9 \mathrm{~cm}$ long; main inflorescence axis lax and pendulous, c. $1 \mathrm{~mm}$ wide, terete, dull, smooth; bracts deciduous, up to $1.5 \mathrm{~mm}$ long. Hypanthium stipitate, stipe c. $15 \mathrm{~mm}$ long; obconic, c. 20 by 8 $\mathrm{mm}$, dull, not visibly gland dotted, minutely wrinkled. Sepals 4 , c. 4 by $6 \mathrm{~mm}$, semicircular, persistent, free. Petals not seen. Stamens not seen. Style up to $9 \mathrm{~cm}$ long. Fruit dark purple, smooth, plane, ellipsoid, c. 5 by $1.5 \mathrm{~cm}$.

Distribution \& Ecology - Vanuatu (Sanma province: Espiritu Santo). Syzygium gracilipes occurs in Fiji and Vanuatu. In Vanuatu the species is known only from Espiritu Santo where it has been collected from cloud montane forest on Mt Tabewemasama between c. 900 and 1800 m asl.

Vernacular names - Putu-havia (Espiritu Santo).

Uses - Unknown.

Notes - 1. Early development of inflorescences occurs in March but the time of flowering is unknown. Insufficient data is available, but one collection in early fruit was made between the months of September to November.

2. The vegetative features of $S$. gracilipes are very similar to those of $S$. samarangense. However, an inflorescence character clearly distinguishes these two species. Syzygium gracilipes has a distinctively long hypopodium of c. $9 \mathrm{~cm}$ whereas $S$. samarangense, it is up to $1 \mathrm{~cm}$ long.

3. Smith (1985) cited the US specimen of the collection U.S. Expl. Exped. S.n. (Fiji) as holotype of S. gracilipes. However, Gray (Gray \& Wilkes 1854) did not designate a holotype specimen and the US material is more appropriately regarded as the lectotype of the name.

\section{Syzygium insulare T.G.Hartley \& L.M.Perry}

Syzygium insulare T.G.Hartley \& L.M.Perry (1973) 183. - Typus: Floyd NGF 3546 (holo A n.v.; iso CANB), Papua New Guinea, New Britain, West Nakanai, Galilo village, near Cape Hoskins, 3 Aug. 1954.

Tree or shrub up to $3 \mathrm{~m}$ tall. Vegetative branchlets terete to terminally compressed, c. $3 \mathrm{~mm}$ diam; bark dull, smooth, not glandular or verrucose, persistent. Leaf lamina c. 26 by 10 $\mathrm{cm}$, broadly ovate; base symmetric, cuneate or retuse; apex acuminate, acumen flat; margin undulate; chartaceous; drying greenish above; primary vein (midrib) c. $1 \mathrm{~mm}$ wide; secondary veins open, c. 13 each side of primary vein, c. $24 \mathrm{~mm}$ apart; intramarginal vein strongly arched, 2-9 $\mathrm{mm}$ from the margin at the lamina midpoint; secondary intramarginal vein weakly arched; tertiary intramarginal vein absent; oil dots present, not visible to the unaided eye in transmitted light, small, moderately dense. Petiole c. 10 by $2 \mathrm{~mm}$, adaxially strongly grooved. Inflorescence terminal, simple dichasia, c. 5 by $4 \mathrm{~cm}, 3$ flowers per anthopodium; hypopodium 8-10 mm long; main inflorescence axis absent; bracts persisting, c. $1 \mathrm{~mm}$ long. Hypanthium stipitate, stipe 1-1.4 cm long; campanulate; c. 4 by $3 \mathrm{~cm}$, dull, not visibly gland dotted, ribbed to generally smooth. Sepals 4 , c. 5 by $13 \mathrm{~mm}$, subcircular, persistent, free. Petals c. 4 , present at anthesis, coherent, semicircular, c. 10 by $20 \mathrm{~mm}$, white; not visibly gland dotted, margin entire. Stamens many, more than 50 , outermost stamens c. $25 \mathrm{~mm}$ long; filament free, white; anther sacs narrowly oblong. Style c. $25 \mathrm{~mm}$ long. Fruit whitish green becoming red when ripe, smooth, plane, fusiform or napiform, up to 16 by $7.5 \mathrm{~cm}$.

Distribution \& Ecology — Vanuatu (Malampa province: Malakula; Penama province: Pentecost; Shefa province: Efate;
Torba province: Banks Islands-Vanua Lava; Torres Islands, Tegua). In Vanuatu, $S$. insulare is restricted to the northern islands where it occurs frequently along the coastal zone, although it may occur inland up to $140 \mathrm{~m}$ asl. Syzygium insulare also occurs in Papua New Guinea and on the Solomon Islands.

Vernacular name - Nepkrera (Malakula).

Uses - The species is not used by local people.

Notes - 1. It has been recorded to flower between August and September and fruit between October and March.

2. Syzygium insulare occurs in the Bismarck Archipelago, Solomon Islands and Vanuatu. This distribution pattern, i.e. Papuasia-Vanuatu, occurs in several other Vanuatu species.

3. Past collections of this species in Vanuatu (with no specific locality) were mistakenly identified as S. nutans (K.Schum.) Merr. \& L.M.Perry. In S. insulare the inflorescence axis is erect whereas in $S$. nutans, it is pendulous. The anthers of $S$. insulare are c. $1 \mathrm{~mm}$ long thus they are conspicuously large and distinctive relative to the other Syzygium species in Vanuatu. Its inflorescence is very short and unbranched, and at most the flowers are in clusters of three.

4. The vegetative features of $S$. insulare can be confused with $S$. richii, however, they are quite distinct in vegetative branchlets, hypanthium and fruit size. In S. insulare, the vegetative branchlets are terete, the hypanthium is up to 4 by $3 \mathrm{~cm}$ and the fruit is up to 16 by $7.5 \mathrm{~cm}$. For $S$. richii, the vegetative branchlets are winged, the hypanthium is up to 2 by $2.5 \mathrm{~cm}$ and the fruit up to 3 by $2.1 \mathrm{~cm}$.

\section{Syzygium jambos (L.) Alston}

Syzygium jambos (L.) Alston (1931) 115. — Eugenia jambos L. (1753) 470. — Typus (fide Fawcett \& Rendle 1926): Herb. Hermann 2: 20, No. 188 (lecto BM n.v.), India

Tree up to $10 \mathrm{~m}$ tall. Vegetative branchlets quadrangular without wing, c. $4 \mathrm{~mm}$ diam; bark dull, striated to longitudinally cracked, not glandular or verrucose, flaking. Leaf lamina up to 14 by $3.4 \mathrm{~cm}$, lanceolate; base symmetric sometimes oblique, cuneate; apex acute, acumen flat; margin flat; coriaceous; drying brown-greenish above; primary vein (midrib) c. $1 \mathrm{~mm}$ wide; secondary veins open, c. 14 each side of primary vein, c. $8 \mathrm{~mm}$ apart; intramarginal vein strongly arched, up to $2.5 \mathrm{~mm}$ from the margin at the lamina midpoint; secondary intramarginal vein weakly arched; tertiary intramarginal vein absent; oil dots present, not visible to the unaided eye in transmitted light, small, sparse. Petiole $4-6$ by $1.5 \mathrm{~mm}$, adaxially slightly grooved. Inflorescence terminal, simple dichasia, up to 2.5 by $4 \mathrm{~cm}$, solitary flower; hypopodium c. 3-7 mm long; main inflorescence axis c. $2 \mathrm{~mm}$ wide, angled, dull, smooth; ebracteate. Hypanthium stipitate, stipe c. $3 \mathrm{~mm}$ long; campanulate, c. 13 by $10 \mathrm{~mm}$, glossy, dotted glands not visible, striate. Sepals 4, c. 4 by 11 $\mathrm{mm}$, semicircular, persistent, free. Petals 4 , not decidious, not coherent, semicircular, $12-20$ by $10-18 \mathrm{~mm}$, not visibly gland dotted, margin entire. Stamens many, more than 50 , outermost stamen c. $4 \mathrm{~cm}$, filaments free, anther sacs not long narrowly elliptic. Style c. $5 \mathrm{~cm}$ long. Fruit white or yellowish, smooth, nearly round to oval, up to $5 \mathrm{~cm}$ wide.

Distribution \& Ecology - Vanuatu (Shefa province: Efate). Syzygium jambos has naturalised in Vanuatu and is also a widely cultivated species in the world.

Vernacular name - Unknown.

Uses - Unknown.

Note - The vegetative features of $S$. jambos can be mistaken for S. gracilipes. In S. jambos, the leaves are smaller, c. 14 by $3 \mathrm{~cm}$, the secondary veins are $8 \mathrm{~mm}$ apart and there are 14 of them on each side of the primary vein. For $S$. gracilipes, the leaves are longer, c. 18 by $6 \mathrm{~cm}$, the secondary veins are 1.8 $\mathrm{cm}$ apart and there are 13 of them on each side of the primary vein. 


\section{Syzygium kajewskii Guillaumin}

Syzygium kajewskii Guillaumin (1931) 256. — Typus: Wilson 970 (lectotype P!, here designated; iso BRI!, K!), Vanuatu, Tafea Province, Aneityum, Anelgauhat Bay, 657 m, Sept. 1929.

Tree up to $25 \mathrm{~m}$ tall. Vegetative branchlets terete, c. $3 \mathrm{~mm}$ diam; bark dull, smooth, not glandular or verrucose, persistent. Leaf lamina $4.5-10.5$ by $2.3-4.9 \mathrm{~cm}$, circular or broadly elliptic; base symmetric, cuneate or attenuate; apex caudate or acute or acuminate, acumen recurved; margin undulate; chartaceous, dried reddish brown above; primary vein (midrib) less than $1 \mathrm{~mm}$ wide; secondary veins closed, more than 20 each side of primary vein, c. $3 \mathrm{~mm}$ apart; intramarginal vein strongly arched, 18-30 $\mathrm{mm}$ from the margin at the lamina midpoint; secondary intramarginal vein weakly arched, tertiary intramarginal vein absent; oil dots present, not visible to the unaided eye in transmitted light, small, sparse to dense. Petiole c. $27 \mathrm{~mm}$ long, somewhat distally curved; adaxially strongly grooved. Inflorescence terminal or cauliflorous, cymose panicle, c. 9 by $12 \mathrm{~cm}$, c. 5-9 flowers per anthopodium; hypopodium 2.5-5 $\mathrm{mm}$ long; main inflorescence axis c. $1 \mathrm{~mm}$ wide, terete, dull, smooth; bracts deciduous, less than $0.5 \mathrm{~mm}$ long. Hypanthium stipitate, stipe c. 1-4 mm long; obconical or campanulate, c. 10 by $8 \mathrm{~mm}$, dull, not visibly gland dotted, glandular-verrucose, smooth. Sepals 4, c. 1 by $2 \mathrm{~mm}$, semicircular, persistent, free. Petals c. 4, deciduous, white, not coherent, circular, less than $1 \mathrm{~mm}$ by $8 \mu \mathrm{m}$, not visibly gland dotted; margin entire. Stamens many, more than 50 , outermost stamens $5-8 \mathrm{~mm}$ long; filament free, white; anther sacs parallel, circular or elliptic. Style c. 6 $\mathrm{mm}$ long. Fruit not seen.

Distribution \& Ecology — Vanuatu (Malampa province: Malakula; Penama province: Pentecost; Sanma province: Espiritu Santo; Shefa Province: Efate, Nguna; Tafea province: Aneityum, Erromango). Syzygium kajewskii is endemic to the Vanuatu archipelago where it occurs quite frequently in the southern islands. The species occurs as a canopy tree in dense forest on slopes and plateaus up to $970 \mathrm{~m}$ asl.

Vernacular names — Nomo thee (Aneityum), neyalam (Erromango).

Uses - Commercial timber, firewood and house posts.

Notes - 1. Syzygium kajewskii is often misidentified as $S$. aneityense, however, these species are distinct in petiole length, hypanthium and sepal size. In S. aneityense the petiole is $5-8 \mathrm{~mm}$ long, the hypanthium is obconic or broadly clavate and up to 10 by $5 \mathrm{~mm}$; the sepals are small to almost inconspicuous $0.2-0.4 \mathrm{~mm}$ long. For $S$. kajewskii, the petiole is c. $27 \mathrm{~mm}$ long; the hypanthium is obconic or campanulate and c. 10 by $8 \mathrm{~mm}$ and the sepals are relatively conspicuous c. 1 by $2 \mathrm{~mm}$. In S. kajewskii, the hypanthium size varies along an altitudinal gradient. In cloud montane forest at c. $900 \mathrm{~m}$ asl it is c. 5 by $3 \mathrm{~mm}$ but below this forest system the hypanthium is c. 10 by $8 \mathrm{~mm}$.

2. When describing S. kajewskii, Guillaumin (1931) cited only one collection, Wilson 970, but did not designate a particular specimen as holotype. In accordance with Recommendation 9A.4 of the ICBN (McNeill et al. 2012), the specimen deposited in Guillaumin's home institution, $\mathrm{P}$, is considered to be the type and is designated lectotype above.

\section{Syzygium malaccense (L.) Merr. \& L.M.Perry}

Syzygium malaccense (L.) Merr. \& L.M.Perry (1938b) 215. - Eugenia malaccensis L. (1753) 470. - Myrtus malaccensis (L.) Spreng. (1825) 484. - Jambosa malaccensis (L.) DC. (1828) 286. - Type: not designated. Jarvis (2007) lists two plates that are available for lectotypification purposes: Herb. Hermann 5: 241, No. 187 [icon] (BM), and Rheede, Hort. Malab. 1: 29, t. 18. 1678.
Tree up to $25 \mathrm{~m}$ tall. Vegetative branchlets terete or slightly quadrangular without wings, c. $6 \mathrm{~mm}$ diam; bark dull, cracked to slightly ribbed, not glandular or verrucose, persistent. Leaf lamina $10.5-25$ by $6.3-7.9 \mathrm{~cm}$, lanceolate or obovate or elliptic; base symmetric, cuneate; apex acute or acuminate, acumen flat; margin slight undulate; chartaceous, drying reddish brown above; primary vein (midrib) c. $1 \mathrm{~mm}$ wide; secondary veins open, 8-13 each side of primary vein, 11-18 mm apart; intramarginal vein strongly arched, 1-6 mm from the margin at the lamina midpoint; secondary intramarginal vein weakly arched; tertiary intramarginal vein absent; oil dots present, visible to the unaided eye in transmitted light, small, dense. Petiole $6-9$ by $2 \mathrm{~mm}$, adaxially strongly grooved. Inflorescence ramiflorous, sometimes cauliflorous, cymose, c. 6 by $3 \mathrm{~cm}, 5-7$ flowers per anthopodium; hypopodium 10-20 mm long; main inflorescence axis c. $2 \mathrm{~mm}$ wide, terete, dull, smooth to longitudinally cracked; ebracteate. Hypanthium pink, stipitate, stipe c. $8 \mathrm{~mm}$ long; clavate to campanulate; c. 3 by $1 \mathrm{~cm}$, dull, not visibly gland dotted, minutely wrinkled. Sepals 4 , c. 4 by $6 \mathrm{~mm}$, semicircular, persistent, free. Petals 4, deciduous, not coherent, rhombic, c. 10 by $10 \mathrm{~mm}$, visibly gland dotted; margin entire. Stamens many, more than 50 , outermost stamens up to $2.3 \mathrm{~cm}$ long; filament free, pink; anther sacs parallel, narrowly oblong or elliptic. Style up to $2.5 \mathrm{~cm}$ long. Fruit green becoming pink or red in ripening, smooth, plane, oblong, c. 2 by $1.5 \mathrm{~cm}$.

Distribution \& Ecology - Vanuatu (Malampa province: Ambrym. Penama province: Pentecost; Sanma province: Espiritu Santo; Shefa province: Efate, Epi; Tafea province: Aneityum, Erromango, Tanna; Torba province: Torres Islands, Banks Islands-Vanua lava). Syzygium malaccense is widespread in the Southeast Asian-Malesian-Southwest Pacific region where it is frequently cultivated. Syzygium malaccense is common throughout the Vanuatu archipelago occurring from sea level to elevations of c. $500 \mathrm{~m}$ asl.

Vernacular names - Ahi-ngakapika (Ambrym); waveh (Erromango); Inyhueg (Aneityum).

Uses - The fruits are edible; the durable hardwood is used for building posts and rafters.

Notes - 1. Records have indicated flowering to occur throughout the year and fruiting between May and November.

2. Syzygium malaccense may represent an early introduction by man to Vanuatu and other Southwest Pacific islands. The species is commonly cultivated because of its edible fruits. It is treated here as being indigenous in Vanuatu.

3. With its mass flowering, the dark pink almost red inflorescence of $S$. malaccense stands out quite conspicuously when observed in the field.

4. Type for $S$. malaccense has not been designated so both plates listed by Jarvis (2007) were opted instead, for lectotypification purposes, with no formal designation.

\section{Syzygium myriadenum Merr. \& L.M.Perry}

Syzygium myriadenum Merr. \& L.M.Perry (1942a) 293. — Eugenia myriadena (Merr. \& L.M.Perry) Whitmore (1967) 16. — Type: Kajewski 2713 (holo A n.v.; iso BRI!), Solomon Islands, Guadalcanal, Sorvorhio Basin, Jan. 1932.

Tree up to $15 \mathrm{~m}$ tall. Vegetative branchlets quadrangular without wings, angled or terminally compressed, c. $5 \mathrm{~mm}$ wide; bark dull, smooth, moderately glandular-verrucose, flaking. Leaf lamina up to 23.5 by $7.2 \mathrm{~cm}$, obovate to broadly oblong; base symmetric, cuneate; apex acute or sometimes round, acumen flat; margin flat; entire; coriaceous; drying greenish brown above; primary vein (midrib) c. $2 \mathrm{~mm}$ wide; secondary veins closed, more than 20 each side of primary vein, c. $5 \mathrm{~mm}$ apart; intramarginal vein strongly arched, $2-4 \mathrm{~mm}$ from the margin at the lamina midpoint; secondary intramarginal vein weakly arched; 
tertiary intramarginal vein absent; oil dots present, not visible to the unaided eye in transmitted light, small, moderately dense. Petiole c. 20 by $2 \mathrm{~mm}$, adaxially strongly grooved. Inflorescence terminal, cymose panicle, c. 8 by $6 \mathrm{~cm}, 1-2$ flowers per anthopodium; hypopodium 5-8 mm long; main inflorescence axis c. $3 \mathrm{~mm}$ wide, compressed, angled, dull, smooth; bracts caducous, not seen. Hypanthium not stipitate; narrowly oblong, c. 17 by $5 \mathrm{~mm}$, dull, not visibly gland dotted, striate. Sepals 4 , c. 1 by $3 \mathrm{~mm}$, triangular or semicircular, persistent, free. Petals not seen. Stamens not seen. Style not seen. Fruit black when ripe, smooth, plane, botuliform, c. 3 by $0.5 \mathrm{~cm}$.

Distribution \& Ecology - (Vanuatu Penama province: Pentecost; Sanma Province: Espiritu Santo; Tafea province: Aneityum, Erromango). Syzygium myriadenum occurs in the Solomon Islands and in Vanuatu where it is quite common in the southern islands rainforest up to $900 \mathrm{~m}$ asl.

Vernacular names - Incaemu (Aneityum); Nettor (Erromango).

Uses - Unknown.

Note - Syzygium myriadenum can be confused with S. nomoa because of the close similarities in leaf shape and secondary venation pattern. However, these two species are distinct in leaf size and apex and in hypanthium shape and size. Syzygium myriadenum has leaves up to 23.5 by $7.2 \mathrm{~cm}$ with the apex acute, and the hypanthium narrowly oblong and c. 17 by $5 \mathrm{~mm}$. For $S$. nomoa the leaves are up to 15.6 by $5.8 \mathrm{~cm}$ with the leaf apex round, and the hypanthium is obconic and c. 8 by $4 \mathrm{~mm}$.

\section{Syzygium nidie Guillaumin}

Syzygium nidie Guillaumin (1931) 257. - Typus: Wilson 984 (lectotype P!, here designated; iso A photo seen, BISH n.v., K!, US n.v.), Vanuatu, Tafea Province, Aneityum, Anelgauhat Bay, rainforest up to 500 m, Sept. 1929.

Tree up to $15 \mathrm{~m}$ tall. Vegetative branchlets terete, c. $4 \mathrm{~mm}$ diam; bark dull, cracked, fading white brownish, not glandular or verrucose, persisting. Leaf lamina up to 6.5 by $3.1 \mathrm{~cm}$, elliptic or sometimes broadly elliptic in lower foliage; base symmetric rarely oblique, attenuate; apex acuminate with conspicuous drip tip, acumen recurved; margin undulate; coriaceous; drying greenish brown above; primary vein (midrib) less than $1.25 \mathrm{~mm}$ wide; secondary veins open, more than 20 each side of primary vein, up to $1.5 \mathrm{~mm}$ apart; intramarginal vein strongly arched, c. $1 \mathrm{~mm}$ from the margin at the lamina midpoint; secondary and tertiary intramarginal vein absent; oil dots present, not visible to the unaided eye in transmitted light, small, sparse. Petiole c. 15 by $1 \mathrm{~mm}$, adaxially slightly grooved. Inflorescence terminal, cymose panicle, c. 7 by $5 \mathrm{~cm}, 2-3$ flowers per anthopodium; hypopodium c. $3 \mathrm{~mm}$ long; main inflorescence axis up to $1.5 \mathrm{~mm}$ wide, terete, dull, smooth; bracts caducous, not seen. Hypanthium not stipitate, campanulate or funnel shaped, c. 14 by 10 $\mathrm{mm}$, dull, not visibly gland dotted, minutely (distinctly) striated. Sepals 4 , c. 2 by $4 \mathrm{~mm}$, triangular, persistent, free. Petals 4 , caducous, coherent, circular, c. 1 by $5-8 \mathrm{~mm}$, not visible to the unaided eye in transmitted light, margin entire. Stamens many, more than 50 , outermost stamens up to $1.6 \mathrm{~cm}$ long; filament free, white; anther sacs elliptic or oblong. Style c. $10 \mathrm{~mm}$ long. Fruit red, smooth, plane, ellipsoid, up to 1.3 by $0.6 \mathrm{~cm}$.

Distribution \& Ecology - Vanuatu (Sanma province: Espiritu Santo; Tafea province: Aneityum). Syzygium nidie occurs in Fiji and in Vanuatu. In Vanuatu it grows in mid-lowland to montane rainforests up to $900 \mathrm{~m}$ asl.

Vernacular names - Nidie or inmejai (Aneityum).

Uses - Hardwood for building; commercial timber.

Notes - 1. Syzygium nidie has a similar inflorescence branching pattern to $S$. myriadenum and $S$. nomoa, but these species are distinct in the following vegetative features: $S$. nidie, leaf apex with a conspicuous drip tip, leaf up to 6.5 by $3.1 \mathrm{~cm}$; S. myriadenum, leaf apex acute, leaf up to 23.5 by $7.2 \mathrm{~cm}$; $S$. nomoa, leaf apex is round, leaf c. 15.6 by $5.8 \mathrm{~cm}$.

2. The vegetative features of $S$. nidie can be confused with S. subcorymbosum, however, the two species are distinct in leaf apex, secondary veins, secondary intramarginal vein and fruit size. In S. nidie the apex forms a distinctive drip tip, the secondary veins are open, the secondary intramarginal vein is weakly arched and fruit is c. 13 by $6 \mathrm{~mm}$. For $S$. subcorymbosum, the leaf apex is acute, the secondary veins are closed, a secondary intramarginal vein is absent and the fruit is $30-46$ by $18-24 \mathrm{~mm}$.

3. When describing S. nidie, Guillaumin (1931) cited only one collection, Wilson 984, but did not designate a particular specimen as holotype. Smith (1985) cited the specimen in A as holotype but there is no evidence that Guillaumin saw the specimen, which has been annotated as an isotype in the hand of L.M. Perry (Emily Wood, pers. comm.). In accordance with Recommendation 9A.4 of the ICBN (McNeill et al. 2006), the specimen deposited in Guillaumin's home institution, $P$, is considered to be the type and is designated lectotype above.

\section{Syzygium nomoa Guillaumin}

Syzygium nomoa Guillaumin (1931) 258. - Typus: Kajewski 128 (lectotype $\mathrm{P}$ !, here designated; iso BRI!, K!), Vanuatu, Tanna, Tafea, Lenakel, rainforest, 200 m, 7 Mar. 1928.

Tree up to $25 \mathrm{~m}$ tall. Vegetative branchlets quadrangular without wings, c. $6 \mathrm{~mm}$ diam; bark dull, smooth, not glandular-verrucose, persistent. Leaf lamina up to 15.6 by $5.8 \mathrm{~cm}$, obovate; base symmetric, attenuate or cuneate; apex retuse or rounded; margin flat; coriaceous; drying greenish brown above; primary vein (midrib) c. $2 \mathrm{~mm}$ wide; secondary veins closed, more than 20 each side of primary vein, c. $2 \mathrm{~mm}$ apart; intramarginal vein strongly arched, c. $2 \mathrm{~mm}$ from the margin at the lamina midpoint; secondary intramarginal vein weakly arched; tertiary intramarginal vein absent; oil dots present, not visible to the unaided eye in transmitted light, small, sparse. Petiole c. 15 $\mathrm{mm}$ long; adaxially strongly grooved. Inflorescence terminal, cymose panicle, $5.5-10$ by $4-14 \mathrm{~cm}, 1-2$ flowers per anthopodium; hypopodium c. $10 \mathrm{~mm}$ long; main inflorescence axis c. $5 \mathrm{~mm}$ wide, quadrangular, dull, smooth; bracts deciduous, c. $2 \mathrm{~mm}$ long. Hypanthium not stipitate, obconic, c. 8 by $4 \mathrm{~mm}$, dull, not visibly gland dotted; striate. Sepals 4 , c. 1 by $3 \mathrm{~mm}$, semicircular, persistent, free. Petals not seen. Stamens many, more than 50, outermost stamens c. $1 \mathrm{~cm}$ long; filament free, colour not seen; anther sacs elliptic. Style c. $4 \mathrm{~mm}$ long. Fruit black when ripe, smooth, furfuraceous, botuliform to ellipsoid, up to 2 by $1.2 \mathrm{~cm}$.

Distribution \& Ecology — Vanuatu (Sanma province: Espiritu Santo; Shefa province: Efate; Tafea province: Aneityum, Erromango, Tanna; Torba Province: Banks islands-Vanua Lava). Syzygium nomoa is endemic to Vanuatu where it is quite common in kauri forest and primary rainforest up to $800 \mathrm{~m}$ asl.

Vernacular names - Incaemohos or incaemu (Aneityum).

Uses - A useful timber for building canoes, and for house posts.

Notes - 1. Flowers have been recorded from March to June and fruits from November to March.

2. Syzygium nomoa can be misidentified as S. myriadenum because of the similarities in vegetative features. However, these two species are distinct in leaf size and apex, hypanthium shape and size. In S. nomoa, the leaf lamina is up to 15.6 by $5.8 \mathrm{~cm}$, the leaf apex is round and the hypanthium is obconic, and c. 8 by $4 \mathrm{~mm}$. For $S$. myriadenum, the leaves are up to 23.5 by $7.2 \mathrm{~cm}$, the leaf apex is acute and the hypanthium is narrowly oblong and c. 17 by $5 \mathrm{~mm}$. 
3. Syzygium nomoa has a similar inflorescence branching pattern to S. myriadenum and S. nidie. However, these species are distinct in leaf apex and size. In S. nomoa the leaf apex is round and the leaves are up to 15.6 by $5.8 \mathrm{~cm}$ whereas in the latter two species the leaf is acute and up to 23.5 by $7.2 \mathrm{~cm}$ and conspicuously acuminate and up to 6.5 by $3.1 \mathrm{~cm}$, respectively.

\section{Syzygium onesimum Merr. \& L.M.Perry}

Syzygium onesimum Merr. \& L.M.Perry (1942a) 296. - Eugenia onesima (Merr. \& L.M.Perry) Whitmore (1967) 17. — Typus: Kajewski 2043 (holo A n.v.; iso BRI!), Papua New Guinea, Bougainville Province, Buin, Koniguru, Aug. 1930.

Tree up to $15 \mathrm{~m}$ tall. Vegetative branchlets terete, c. $2 \mathrm{~mm}$ diam; bark dull, very striate, not glandular or verrucose, persistent. Leaf lamina up to 8 by $3.3 \mathrm{~cm}$, ovate to elliptic; base symmetric, attenuate; apex acuminate, acumen recurved; margin undulate; coriaceous; drying greenish above; primary vein (midrib) 0.5 $\mathrm{mm}$ wide; secondary veins open, more than 20 each side of primary vein, c. $2 \mathrm{~mm}$ apart; intramarginal vein strongly arched, c. $2 \mathrm{~mm}$ from the margin at the lamina midpoint; secondary intramarginal vein weakly arched, tertiary intramarginal vein absent; oil dots present, not visible to the unaided eye through transmitted light, small, dense. Petiole c. $13 \mathrm{~mm}$ long; adaxially strongly grooved. Inflorescence terminal, cymose panicle; c. 10 by $8 \mathrm{~cm}, 3$ flowers per anthopodium; hypopodium $2 \mathrm{~mm}$ long; main inflorescence axis c. $1 \mathrm{~mm}$ wide, terete, dull, smooth; bracts caducous, not seen. Hypanthium stipitate, stipe c. 2 $\mathrm{mm}$ long, obconic, c. 4 by $2 \mathrm{~mm}$, dull, not visibly gland dotted, minutely wrinkled. Sepals not seen. Petals not seen. Style c. $3 \mathrm{~mm}$ long. Fruit purple, smooth, plane, ellipsoid or spherical or obconical, c. 2 by $1.6 \mathrm{~cm}$.

Distribution \& Ecology — Vanuatu (Sanma province: Espiritu Santo; Shefa province: Efate). Syzygium onesimum occurs in Papua New Guinea, Solomon Islands and Vanuatu. In Vanuatu, the species has been collected in montane rainforest at c. 900 $\mathrm{m}$ asl.

Vernacular names - Unknown.

Uses - Unknown.

Notes -1 . The flowering period is unknown but its fruits have been recorded in November.

2. In Vanuatu, S. onesimum has been incorrectly referred to as $S$. buettnerianum Nied.

3. Syzygium subcorymbosum could be misidentified as S. onesimum, however, these two species may be distinguished by fruit size and colour. In S. onesimum the fruit is ellipsoid or spherical or obconioid, c. 18 by $14 \mathrm{~mm}$ and purple. For S. subcorymbosum it is barrel-shaped to depressed spheroidal, 30-46 by $18-24 \mathrm{~mm}$ and yellow.

\section{Syzygium richii (A.Gray) Merr. \& L.M.Perry}

Syzygium richii (A.Gray) Merr. \& L.M.Perry (1942b) 77. - Eugenia richii A.Gray (in Gray \& Wilkes 1854: 510). - Jambosa richii (A.Gray) Müll.Berol. (1858) 849. - Typus (fide Smith 1985, as holotype): U.S. Expl. Exped. s.n. (lecto US n.v.; ?iso GH n.v.), Fiji, 1840.

Tree up to $10 \mathrm{~m}$ tall. Vegetative branchlets winged, 4-6 mm diam; bark dull, smooth, not glandular-verrucose, persistent. Leaf lamina up to 23.5 by $13.2 \mathrm{~cm}$, broadly elliptic; base symmetric, cordate; apex rounded to acute, acumen flat; margin undulate; chartaceous; drying reddish brown above; primary vein (midrib) c. $2 \mathrm{~mm}$ wide; secondary veins open, 10-15 each side of primary vein, c. $4 \mathrm{~cm}$ apart; intramarginal vein strongly arched, 4-7 mm from the margin at the lamina midpoint; secondary intramarginal vein weakly arched; tertiary intramarginal vein absent; oil dots present, not visible to the unaided eye in transmitted light, small, dense. Petiole c. $12 \mathrm{~mm}$ long, adaxi- ally strongly grooved. Inflorescence terminal, cymose panicle, up to 5 by $8.5 \mathrm{~cm}, 1-3$ flowers per anthopodium; hypopodium c. $10 \mathrm{~mm}$ long; main inflorescence axis up to $3 \mathrm{~mm}$ wide, winged, dull, smooth; bracts persisting, c. $2 \mathrm{~mm}$ long. Hypanthium not stipitate; obconical, up to 2.8 by $2 \mathrm{~cm}$, dull, not visibly gland dotted; smooth. Sepals 4, c. 6 by $10 \mathrm{~mm}$, semicircular, persistent, free. Petals c. 5, deciduous, not coherent, circular, up to 1.4 by $1.1 \mathrm{~cm}$, visibly gland dotted, margin lacerate. Stamens many, more than 50 , outermost stamens up to $3.5 \mathrm{~cm}$ long; filament free, yellow; anther sacs narrowly elliptic. Style up to $3.5 \mathrm{~cm}$ long. Fruit yellow, smooth, plane, barrel-shaped, C. 3 by $2.1 \mathrm{~cm}$.

Distribution \& Ecology — Vanuatu (Malampa province: Paama; Penama province: Pentecost; Shefa province: Efate; Tafea province: Aneityum, Aniwa, Erromango, Tanna). Syzygium richii occurs in Fiji and Vanuatu and in the latter it frequently occurs in the shoreline/coastal strand vegetation and has also been collected in lowland secondary forest up to 100-300 m asl.

Vernacular names - Gavigaganatanata (Banks Islands); kavika andemat is interpreted as 'kavika of the devil' (Paama island) because of the inedible and sour taste of the fruit.

Uses - Hardwood that is used as ground posts; the fruit is inedible.

Notes - 1. Flowers and fruits have been recorded throughout the year.

2. Syzygium richii is largely a coastal species that occupies similar habitats in Fiji and Vanuatu.

3. Syzygium richii has been mistakenly identified as S. flabellum because of the similarities in leaf and hypanthium size and shape. These species are different in that $S$. richii has winged vegetative branchlets, the leaf base is cordate, the petiole c. $12 \mathrm{~mm}$ long and the hypanthium white, obconical and up to 2.8 by $2 \mathrm{~cm}$. For $S$. flabellum the vegetative branchlets are terete, the leaf base truncate, the petiole up to $3.5 \mathrm{~cm}$ long and the hypanthium yellow, campanulate and up to 2.5 by $2.3 \mathrm{~cm}$. For a comparison with $S$. samarangense, see under that species.

4. Smith (1985) cited the US specimen of the collection U.S. Expl. Exped. s.n. (Fiji, 1840) as holotype of E. richii. However, Gray (Gray \& Wilkes 1854) did not designate a holotype specimen and the US material is more appropriately regarded as the lectotype of the name.

\section{Syzygium samarangense (Blume) Merr. \& L.M.Perry}

Syzygium samarangense (Blume) Merr. \& L.M.Perry (1938a) 115. - Myrtus samarangensis Blume (1826) 1084. - Jambosa samarangensis DC (1828) 286. - Typus "in cultis". The type has not yet been established but $P$. Hovenkamp (pers. comm.) advises that specimens in $L$ are likely to be original material.

Tree up to $10 \mathrm{~m}$ tall. Vegetative branchlets terete or quadrangular, 3-5 mm diam; bark dull, smooth to slightly ribbed, sparsely glandular or verrucose, persistent. Leaf lamina up to 15 by $7.7 \mathrm{~cm}$, ovate; base symmetric, cordate or cuneate; apex acute or short acuminate, acumen flat; margin flat to slightly undulate; coriaceous; drying reddish brown above; primary vein (midrib) up to $1.5 \mathrm{~mm}$ wide; secondary veins open, 7-14 each side of primary vein, c. $11 \mathrm{~mm}$ apart; intramarginal vein strongly arched, c. $6 \mathrm{~mm}$ from the margin at the lamina midpoint; secondary intramarginal vein weakly arched; tertiary intramarginal vein absent; oil dots present, not visible to the unaided eye in transmitted light, small, dense. Petiole subsessile to sessile, c. $3 \mathrm{~mm}$ long, adaxially strongly grooved. Inflorescence terminal, cymose panicle, $2.5-7$ by $2-7 \mathrm{~cm}, 3-5$ flowers per anthopodium; hypopodium c. $5 \mathrm{~mm}$ long; main inflorescence axis c. $1 \mathrm{~mm}$ wide, terete, dull, smooth; bracts deciduous, c. $2 \mathrm{~mm}$ long. Hypanthium stipitate, stipe c. $3 \mathrm{~mm}$ long; obconic; c. 12 by 8 $\mathrm{mm}$, dull, dotted glands visible, slightly ribbed. Sepals 4 , c. 8 by 
$8 \mathrm{~mm}$, subcircular, persistent, free. Petals not seen. Stamens many, more than 50 , outermost stamens c. $2 \mathrm{~cm}$ long; filaments free, creamy white; anther sacs narrowly elliptic. Style c. $2 \mathrm{~cm}$ long. Fruit red when ripe, smooth, plane, depressed spheroidal, up to 1.8 by $1.4 \mathrm{~cm}$.

Distribution \& Ecology — Vanuatu (Malampa province: Paama; Shefa province: Efate; Tafea province: Aneityum). Syzygium samarangense is a widely cultivated species and its natural range has not been established unequivocally (Smith 1985). In Vanuatu, the species appears quite common along the coastal zone (pers. observ.) and appears to be restricted to the northern islands of the archipelago.

Vernacular names - Nakavika (Efate), indahu (Aneityum). Uses - Edible fruit.

Notes - 1. Flowers have been recorded between July and August, and fruit in July.

2. Syzygium samarangense could be misidentified as S. richii and the two may be distinguished as follows: $S$. samarangense: leaf up to 15 by $7.7 \mathrm{~cm}$, vegetative branchlet terete or quadrangular but not winged, hypanthium c. 12 by $8 \mathrm{~mm}$; S. richii: leaf up to 23.5 by $13.2 \mathrm{~cm}$, vegetative branchlet quadrangular with wings, hypanthium c. 28 by $20 \mathrm{~mm}$.

\section{Syzygium seemannii (A.Gray) Biffin \& Craven}

Syzygium seemannii (A.Gray) Biffin \& Craven (in Biffin et al. 2005) 386. — Acicalyptus seemannii A.Gray (1862) 35. - Calyptranthes seemanni (A.Gray) Seem. (1866) 81. - Cleistocalyx seemanni (A.Gray) Merr. \& L.M.Perry (1937) 330. - Typus (fide Smith 1985, as holotype): Seemann 168 (lecto $\mathrm{GH}$; iso BM n.v., K), Fiji, Vanua Levu, the coast of Macuata Province, 1860.

Tree up to $6 \mathrm{~m}$ tall. Vegetative branchlets terete, c. $6 \mathrm{~mm}$ diam; bark dull, cracked to slightly ribbed, not glandular or verrucose, persistent. Leaf lamina up to 7 by $3.5 \mathrm{~cm}$, elliptic; base symmetric, attenuate or cuneate; apex long acuminate, acumen flat; margin slightly undulate; coriaceous; drying reddish brown above; primary vein (midrib) c. $1 \mathrm{~mm}$ from the lamina midpoint; secondary veins closed, 11 each side of primary vein, c. $5 \mathrm{~mm}$ apart; intramarginal vein strongly arched, c. $1 \mathrm{~mm}$ from the lamina midpoint; secondary intramarginal vein weakly arched, tertiary intramarginal vein absent; oil dots present, not visible to the unaided eye in transmitted light, small, moderately dense to dense. Petiole slightly decurrent, c. $10 \mathrm{~mm}$ long, adaxially strongly grooved. Inflorescence terminal to axillary, paniculate cyme, $2.5-6$ by $2-4.5 \mathrm{~cm}, 1-3$ flowers per anthopodium; hypopodium c. $2 \mathrm{~mm}$ long; main inflorescence axis less than $1 \mathrm{~mm}$ wide, terete, dull, smooth to longitudinal slits; bracts caducous, not seen. Hypanthium stipitate, stipe c. $2 \mathrm{~mm}$ long; subspheroidal or conical to narrowly oblong, c. 12 by $5 \mathrm{~mm}$, dull, not visibly gland dotted, smooth. Sepals fused into a calyptra, falling at anthesis. Petals not seen. Stamens many, more than 50 , outermost stamen c. $3 \mathrm{~mm}$ long; filament free, white; anther sacs yellow, circular. Style c. $3 \mathrm{~mm}$ long. Fruit purple to black, smooth, plane, depressed spheroidal, up to 2 by $1.5 \mathrm{~cm}$.

Distribution \& Ecology — Vanuatu (Tafea province: Aneityum). Syzygium seemanni occurs in Fiji and Vanuatu; in Vanuatu it is a rainforest species that occurs up to $700 \mathrm{~m}$ asl on the southern-most islands, Aneityum.

Vernacular names - Inmejai (Aneityum).

Uses - Unknown.

Notes - 1. Flower and fruit have been recorded in June.

2. Syzygium seemannii is a very distinct species in Vanuatu due to the calyptrate calyx and the narrowly oblong hypanthium. In vegetative features, this species is similar to $S$. aneityense, except that the leaf lamina of the latter species is not decurrent.

3. Smith (1985) cited the GH specimen of the collection U.S. Expl. Exped. s.n. (Fiji, 1860) as holotype of $A$. seemannii. However, Gray (1862) did not designate a type specimen and the $\mathrm{GH}$ material is more appropriately regarded as the lectotype.

\section{Syzygium subcorymbosum Merr. \& L.M.Perry}

Syzygium subcorymbosum Merr. \& L.M.Perry (1942a) 297. — Typus: Brass 5573 (holo A photo seen), Papua New Guinea, Central Province, Kubuna, 100 m, Nov. 1933.

Tree up to 15-20 m tall. Vegetative branchlets terete, c. 4-6 mm diam; bark dull, longitudinally cracked, not glandular-verrucose, persistent. Leaf lamina up to 8.6 by $3.7 \mathrm{~cm}$, elliptic; base symmetric, attenuate, slightly decurrent to the petiole acuminate; apex acuminate, acumen recurved; margin slightly undulate; coriaceous; drying reddish brown above; primary vein (midrib) less than $1 \mathrm{~mm}$ wide; secondary veins closed, more than 20 each side of primary vein, c. $3 \mathrm{~mm}$ apart; intramarginal vein strongly arched, c. $2 \mathrm{~cm}$ from the margin at the lamina midpoint; secondary intramarginal vein weakly arched; tertiary intramarginal vein absent; oil dots present, not visible to the unaided eye in transmitted light, small, moderately dense. Petiole c. $10 \mathrm{~mm}$ long; adaxially slightly grooved. Inflorescence terminal, cymose panicle, c. 10 by $11 \mathrm{~cm}$, cluster of 3; hypopodium absent; main inflorescence axis c. $3 \mathrm{~mm}$ wide, terete to quadrangular, rounded, dull, smooth; bracts deciduous, not seen. Hypanthium not stipitate, clavate, c. 8 by $4 \mathrm{~mm}$, glossy, not visibly gland dotted, smooth. Sepals 4 , subcircular, up to 0.5 by $3 \mathrm{~mm}$, persistent, free. Petals not seen. Stamens numerous; filaments free, white; anther sacs elliptic, up to 4 by 2 $\mu \mathrm{m}$. Style c. $5 \mathrm{~mm}$ long. Fruit yellow, smooth to ribbed, plane, barrel-shaped to depressed spheroidal, 30-46 by $18-24 \mathrm{~mm}$.

Distribution \& Ecology — Vanuatu (Malampa province: Paama; Penama province: Pentecost; Shefa province: Efate). Syzygium subcorymbosum occurs in Papua New Guinea, Solomon Islands and Vanuatu. It is a common rainforest tree that occurs from sea level up to $400 \mathrm{~m}$ asl.

Vernacular names - Nguna-ha (Efate); Aiwun (Paama); Haa (Pentecost).

Uses - General timber, firewood, ground posts.

Notes - 1. Flowers have been recorded throughout the year and fruit in June and July.

2. In Vanuatu, S. subcorybosum is sometimes misidentified as S. buettnerianum Nied.

3. Syzygium subcorymbosum could be misidentified as S. onesimum, however, these two species are differentiated in fruit size and colour. In $S$. onesimum the fruit is ellipsoid or spheroidal or obconoidal, up to 1.8 by $1.4 \mathrm{~cm}$ and purple. For S. subcorymbosum it is barrel-shaped to depressed spheroidal, $3-4.6$ by $1.8-2.4 \mathrm{~cm}$ and yellow.

\section{Syzygium tierneyanum (F.Muell.) T.G.Hartley \& L.M.Perry}

Syzygium tierneyanum (F.Muell.) T.G.Hartley \& L.M.Perry (1973) 200. - Eugenia tierneyana F.Muell. (1865) 14. — Typus (fide Hyland 1983): Dallachy s.n. (lecto MEL n.v.), Australia, Queensland, Dalrymple Creek.

Tree up to $25 \mathrm{~m}$ tall. Vegetative branchlets terete, c. $4 \mathrm{~mm}$ diam; bark dull, smooth to slightly striate, not glandular-verrucose, persistent. Leaf lamina up to 15 by $6.6 \mathrm{~cm}$, circular or elliptic; base symmetric, mostly cuneate sometimes attenuate; apex cuspidate or acute or acuminate, acumen recurved; margin flat or undulate; chartaceous; drying greenish above; primary vein (midrib) c. $1 \mathrm{~mm}$ wide; secondary veins open, 7-11 each side of primary vein, $18-28 \mathrm{~mm}$ apart; intramarginal vein absent; secondary and tertiary intramarginal vein absent; oil dots present, not visible to the unaided eye in transmitted light, small, dense. Petiole 6-15 mm long; adaxial strongly grooved. Inflorescence terminal-axillary or lateral, cymose panicle, up to 6.5 by $3.5 \mathrm{~cm}, 5-7$ flowers per anthopodium; hypopodium c. $7 \mathrm{~mm}$ long; main inflorescence axis c. $2 \mathrm{~mm}$ wide, terete, dull, smooth; bracts deciduous, less than $0.5 \mathrm{~mm}$ long. $\mathrm{Hy}$ panthium stipitate, stipe c. $5 \mathrm{~mm}$ long; campanulate; $11-14$ by 


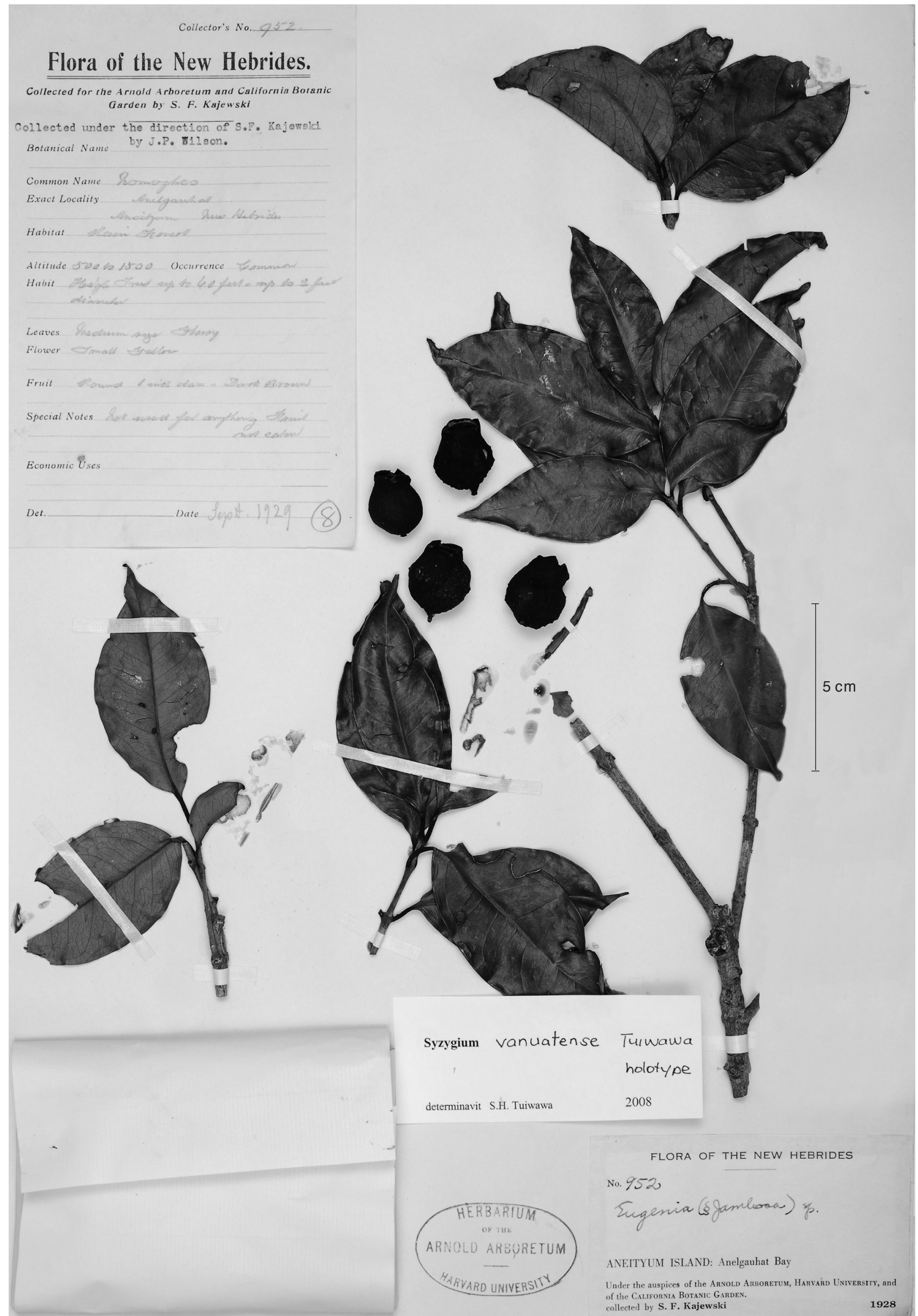

Fig. 2 Holotype of S. vanuatuense S.H.Tuiwawa \& Craven 
10-13 mm, dull, not visibly gland dotted; glandular-verrucose. Sepals 4 , c. 2 by $3-8 \mathrm{~mm}$, semicircular, persistent, free. Petals 4-5, white, persistent, coherent, subcircular, c. 5 by $10 \mathrm{~mm}$, not visibly gland dotted; margin entire. Stamens many, more than 50 , outermost stamens up to $1.5 \mathrm{~cm}$ long; filament not seen; anther sacs narrowly oblong. Style up to $1.7 \mathrm{~cm}$ long. Fruit black to deep red when ripe, smooth, plane, campanuloid, $2.5-3$ by $2-2.5 \mathrm{~cm}$.

Distribution \& Ecology - Vanuatu (Sanma province: Espiritu Santo, Malakula; Tafea province: Aneityum, Erromango, Tanna; Torba province: Hiu, Tegua). Syzygium tierneyanum occurs in Indonesia (Papua Province), Papua New Guinea, Australia, Solomon Islands and Vanuatu. In Vanuatu it is a rainforest species that occurs up to $1200 \mathrm{~m}$ asl.

Vernacular names - Indahau (Aneityum), nahromyein or nemonu (Erromango); Malahavia (E. Santo).

Uses - Good firewood. This species is often logged commercially but is not used for ground posts because it quickly rots in the ground.

Notes - 1. Flowers have been recorded from September to December and fruit from May to December.

2. In Vanuatu, S. tierneyanum displays considerable variability in leaf lamina shape, that is absent any of the non-Vanuatu collections.

3. The inflorescence of $S$. tierneyanum can be confused with those of S. malaccense. However, in S. tierneyanum the inflorescence occurs among or below the leaves and has bracts that are deciduous, whereas for $S$. malaccense the inflorescence occurs only below the leaves and the bracts are caducous.

\section{Syzygium vanuatuense S.H.Tuiwawa \& Craven, sp. nov. - Fig. 2}

A S. aneityensi Guillaumin venis secundariis c. $18 \mathrm{~mm}$ distantibus, vena intramarginali $4 \mathrm{~mm}$ a margine, sepalis majoribus (in fructu $2 \times 5-8 \mathrm{~mm}$ ) differt. - Typus: Wilson 952 (holo A; iso K, P), Vanuatu, Aneityum, Anelgauhat Bay, c. 150-460 m asl, Sept. 1929.

Tree up to $25 \mathrm{~m}$ tall. Vegetative branchlets terete, c. $4 \mathrm{~mm}$ diam; bark dull, smooth, not glandular or verrucose, persistent. Leaf lamina up to 11 by $5.5 \mathrm{~cm}$, circular or elliptic; base symmetric, attenuate or cuneate; apex cuspidate, acumen recurved; margin flat, entire; chartaceous; drying reddish brown above; primary vein (midrib) weak, c. $1 \mathrm{~mm}$ thick; secondary veins open, c. 7 each side of primary vein, up to $1.8 \mathrm{~cm}$ apart; intramarginal vein strongly arched, c. $4 \mathrm{~mm}$ from the margin at the lamina midpoint; secondary intramarginal vein weakly arched, tertiary intramarginal vein absent; oil dots present, not visible to the unaided eye in transmitted light, small, dense. Petiole 6-15 mm, adaxially strongly grooved. Inflorescence not seen. Hypanthium not seen. Sepals 4 , up to 2 by $5-8 \mathrm{~mm}$, semicircular, persistent, free. Petals not seen. Stamens not seen. Style not seen. Fruit red when ripe, smooth, plane, ellipsoid, up to 2.5 by $2 \mathrm{~cm}$.

Distribution \& Ecology - Vanuatu (Tafea province: Aneityum, Erromango). Syzygium vanuatuense is endemic to Vanuatu where it is a rainforest canopy tree occurring up to $400 \mathrm{~m}$ asl.

Vernacular names - Morekolon or neyalam (Erromango). Uses - Unknown.

Notes - 1. Flowers have been recorded in March and fruit in June.

2. In the notes on the label of Wilson 952 the flowers are said to be yellow but no flowers are present on any of the specimens examined.

3. The specific epithet is derived from the country name, Vanuatu.

4. Differs from $S$. aneityense in the following features: secondary veins c. $18 \mathrm{~mm}$ apart, intramarginal vein $4 \mathrm{~mm}$ from the margin, sepals larger (in fruit 2 by $5-8 \mathrm{~mm}$ ).
Acknowledgements The culmination of several institutions and people whose contribution to this project are especially acknowledged: the Fiji Government via the Fijian Affairs Board (FAB) is accredited for financially supporting the graduate study; the ANU Travel Grant Award for co-funding the field expedition to Vanuatu; and the Research School of Biology (ANU) Molecular lab for the laboratory expenditures. The directors and/or curators of the following herbaria are thanked for the opportunity to study collections in their care: A, BISH, BRI, CANB, GH, K, NOU, NZFRI, P, SUVA. The staff and researchers at CSIRO Plant Industry and the Research School of Botany (ANU) are also thanked for the collegial support. The outline maps are based on the map in Higuchi (1996) and have been adapted by VRU CSIRO Plant Industry.

We also thank the staff at the Forestry Departments and other departments of Vanuatu for the technical support: Presley Dovo on Efate, Dick Tomers, the Director of Agriculture, Bani William of GTZ on Espiritu Santo; and the Forestry officers on the islands of Espiritu Santo, Efate and Aneityum. In Fiji: Senivalati Vido at the Fiji Forestry Department in Suva and the parataxonomists Mosese and Mitieli of Nakavu, Namosi Province.

A special 'thank you tumas' to all the chiefs, families, local guides and the unmentioned support group of people who have attributed to the success of the collection and trip: Chief Lolos and the villagers of Butmas village of Espiritu Santo, Chief Selta of Lasenui village and villagers of Waiaru village of Malakula, Chief Sam Tao of Lonamilo village, Chief David of Ihili village and Lalep of Aneityum. Last but not the least a very big 'vinaka vakalevu' to: the Sam family on Walla village, Malakula Island; the Tafua family on Tanna Island; Aga McCartney and the Baereleo family - Rolenas, Kingsley and Dietry for the hospitality and support in the field on Efate and especially on Tanna Island.

\section{REFERENCES}

Alston AHG. 1931. Syzygium. In: Trimen H, Handbook to the flora of Ceylon. 6. Suppl. 112-118.

Biffin E, Craven LA, Tuiwawa M, Crisp MD, Gadek PA. 2005. South Pacific Cleistocalyx transferred to Syzygium (Myrtaceae). Blumea 50: 383-388.

Blume CL. 1826. Bijdragen tot de Flora van Nederlandsch Indië. Volume 1. Ter Lands Drukkerij, Batavia.

Briggs BG, Johnson LAS. 1979. Evolution in the Myrtaceae: evidence from inflorescence structure. Proceedings of the Linnean Society of New South Wales 102: 158-256.

Craven LA. 2001. Unravelling knots or plaiting rope: what are the major taxonomic strands in Syzygium sens.lat. (Myrtaceae) and what should be done with them? In: Saw LG, Chua LSL, Khoo KC (eds), Taxonomy: The cornerstone of biodiversity. Proceedings of the fourth Flora Malesiana symposium: 75-85. Forest Research Institute, Kuala Lumpur, Malaysia.

Craven LA, Biffin E. 2010. An infrageneric classification of Syzygium (Myrtaceae). Blumea 55: 94-99.

Dawson JW. 1999. Myrtaceae. Myrtoideae I: Syzygium. In: Morat P (ed), Flore de la Nouvelle-Calédonie 23, Muséum de l'Histoire Naturelle, Paris. De Candolle AP. 1828. Myrtaceae. Prodromus systematis vegetabilis. Treuttel \& Würtz, Paris.

Druce GC. 1914. Report Botanical Society and Exchange Club of the British Isles 3: 418.

Fawcett W, Rendle AB. 1926. Flora of Jamaica. British Museum, London.

Giovanelli J. 1966. Dix années d'observations météorologiques aux Nouvelles-Hébrides: 1956-1966. Établi et publié par le Service de la météorologie en Nouvelle-Calédonie. Nouméa, New Caledonia.

Gray A. 1862. Plantae Vitienses Seemannianiae. Bonplandia (Hannover) 10: $34-37$

Gray A, Wilkes C. 1854. United States Exploring Expedition, U.S.N. Vol. XV, Botany: Phanerogams. Sherman Printer, Philadelphia, USA.

Guillaumin A. 1931. Contribution to the Flora of the New Hebrides. Journal of the Arnold Arboretum 12, 4: 255-258.

Hartley TG, Craven LA. 1977. A revision of the Papuasian species of Acmena (Myrtaceae). Journal of the Arnold Arboretum 58: 325-342.

Hartley TG, Perry L. 1973. A provisional key and enumeration of species of Syzygium (Myrtaceae) from Papuasia. Journal of the Arnold Arboretum 54: 160-227.

Higuchi M. 1996. Map of Vanuatu. Bulletin of the National Science Museum, Tokyo, Series B, 22: 114, f. 1.

Hyland B. 1983. A revision of Syzygium and allied genera (Myrtaceae) in Australia. Australian Journal of Botany 9: 1-164.

Jarvis CE. 2007. Order out of chaos: Linnaean plant names and their types Linnean Society of London, London.

Kostermans AJGH. 1981. Eugenia, Syzygium and Cleistocalyx (Myrtaceae) in Ceylon: a monographical revision. Quarterly Journal of the Taiwan Museum 34: 117-188. 
Linnaeus C. 1753. Species plantarum, exhibentes plantas rite cognitas, ad genera relates, 1st ed. Holmiae, impensis L. Salvii.

McNeill J, Barrie P, Burdet H, Demoulin V, Hawksworth D, et al. 2012. International code of nomenclature for algae, fungi and plants (Melbourne Code), Adopted by the Eighteenth International Botanical Congress Melbourne, Australia, July 2011. Bratislava, International Association for Plant Taxonomy.

Merrill ED, Perry LM. 1937. Reinstatement and revision of Cleistocalyx Blume (including Acicalyptus A.Gray), a valid genus of the Myrtaceae. Journal of the Arnold Arboretum 18: 322-344.

Merrill ED, Perry LM. 1938a. On the Indo-Chinese species of Syzygium Gaertner. Journal of the Arnold Arboretum 19: 99-116.

Merrill ED, Perry LM. 1938b. The Myrtaceae of China. Journal of the Arnold Arboretum 19: 191-247.

Merrill ED, Perry LM. 1942a. Plantae Papuanae Archoldianae IX. Journal of the Arnold Arboretum 23: 233-297.

Merrill ED, Perry LM. 1942b. Myrtaceae. Sargentia 1: 74-78.

Mueller F. 1865. Eugenia tierneyana. Fragmenta phytographiae australiae 5. Joannis Ferres, Melbourne.

Müller C. 1858. Syzygium clusiifolium, Jambosa richii, Jambosa gracilipes. Annales Botanices Systematicae 4: 839-849.

Parnell JAN, Craven LA, Biffin E. 2006. Matters of scale: dealing with one of the largest genera of angiosperms. In: Hodgkinson TR, Parnell JAN (eds), Reconstructing the Tree of Life: Taxonomy and systematics of species rich taxa: 251-273. CRC Press.

Seemann BC. 1866. Flora vitiensis: a description of the plants of the Viti or Fiji islands, with an account of their history, uses and properties. Reeve \& Co., London.

Skeels HC. 1912. United States Department of Agriculture Bureau of Plant Industry Bulletin 248: 25.

Smith AC. 1985. Flora Vitiensis Nova: A new Flora of Fiji (Spermatophytes only). Volume 3. Pacific Tropical Botanical Garden, Lawai, Hawaii.

Sprengel CPJ. 1825. Systema Vegetabilium, editio decima sexta. Gottingae. Verdcourt B. 2001. Flora of Tropical East Africa: Myrtaceae: 72. Balkema, Rotterdam.

Walter A, Sam C. 2002. Fruits of Oceania. Canberra, Australia.

Wheatley JI. 1992. A guide to the common trees of Vanuatu: with lists of their traditional uses \& ni-Vanuatu names. Department of Forestry, Port Vila, Vanuatu.

Whistler A. 1988. A revision of Syzygium (Myrtaceae) in Samoa. Journal of the Arnold Arboretum 69: 167-192.

Whitmore TC. 1967. Notes on the systematy of Solomon Islands' plants and some of their New Guinea relatives, I-VII. Gardens' Bulletin Singapore 22: 1-21.

\section{IDENTIFICATION LIST}

Numbers after the specimen numbers refer to the species numbers in this revision.

Bennett RSNH 4001: 18 - Bernardi 13184: 11; 13196: 2 - Beveridge RSNH 3008: 13 - Beveridge, Ecroyd, Mitchell NHA 93: 17; NHA 368: 10; TS 6: 2 - Bourdy 744: 7; 1133: 4; 1338: 10 - Burton 147: 19.

Cabalion 286: 3; 289: 10; 833: 7; 1128: 3; 1277: 14; 1345: 9; 2599: 15 2624: 10; 2837: 6; 2850: 6; 2986: 7 - Chanel 87: 15; 116: 8; 167: 9; 245: 10 - Chew RSNH 100: 15; 201: 6; 215: 6; 370: 7 - Clunies-Ross CCR20: 13 - Cribb \& Wheatley 114: 16 - Curry 28: 9; 608: 13; 1251: 19; 1290: 3 1347: 7 ; 1459: 3; 1515: 9.

Gilbert 7 p.p.: 11; 7 p.p.: 13; 8: 12; 44: 13 - Gillison RSNH 3543: 3 - Gillison \& Beveridge RSNH 3502: 10 - Gowers NH90: 4; NH146: 19; NH157: 2 Green RSNH 1066: 10; 1088: 5 - Green, Allen RSNH 1216: 15.

Henderson NHA 9: 10.

Johnson 27: 19; 37: 11; 40: 20; 48 p.p.: 9; 48 p.p.: 20; 57: 11 - Josiah 52: 3. Kajewski 36: 10; 53: 3; 128: 13; 197: 18; 255: 10; 340: 20; 472: 10; 807: 2; 839: 11; 846: 1 - Kamasteia 6: 2; 8: 12; 10: 17; 33: 3; 44: 13 - Kichikichi 7: 11 McKee RSNH 24178: 6; 45608: 15 - Mitchell 19515: 4 - Morat 5857: 15; 5887: 19; 6453: 13 - Munzinger 3668: 14; 3728: 11; 3756: 13; 3886: 13 ; 3897: 14 - Munzinger, Corbara, Tuiwawa 3602: 9 - Munzinger, Lowry, Tuiwawa 3654: 9; 3661: 9; 3671: 9; 3675: 12; 3727: 9; 3741: 9 - Munzinger, Lowry, Tuiwawa, McPherson, Serein 3742: 12; 3751: 9.

Raynal RSNH 16259: 11; 16378: 6.

Schmid 3263: 19; 3264: 3; 3614: 10; 3617: 19; 3618: 19; 3786: 2; 3973: 13 3976: 5; 3977: 19; 4216: 11; 4772: 15; 4773: 19; 5120: 9 - Suprin 300: 6; 328: 19

Thomerson 19542: 8.

Uhe 1642: 15

Veillon 4006: 6 ; 5563: 15.

Walter 316: 10; 406: 7 - Wheatley 123: 18; 129: 15; 274: 9; 304: 10; 431: 10; 469: 7; 611: 15; 620: 16; 654: 18; 710: 9; 720: 15; 765: 9; 769: 12; 775: 2; 808: 3 - Wilson 948: 13; 952: 20; 970: 9; 973: 3; 984: 12; 1003: 10. 